\title{
Regional Policy Variation in Germany: The Diversity of Living Conditions in a 'Unitary Federal State'
}

by:

Charlie Jeffery and Niccole M. Pamphilis (University of Edinburgh)

Carolyn Rowe and Ed Turner (Aston University)

\begin{abstract}
The German federal system is conventionally understood as highly coordinated between federal and regional governments and aimed at producing a 'uniformity' of living conditions. This view has increasingly been challenged as new work focuses on innovation and diversity at the regional level, and also as a consequence of reforms to the federal system that took place in 2006. This article attempts to establish a more systematic basis for assessing and explaining the scope and significance of regional policy variation in Germany. Our findings suggest that - despite institutional structures that foster intense coordination between central and regional governments and apparent popular preferences for uniformity of policy outcomes- the extent of policy variation in Germany is much greater than conventionally understood and driven both by structural factors and partisan choices at the regional level.
\end{abstract}

Keywords: German Federalism; Policy Variation; Political Parties 


\section{INTRODUCTION - SHIFTING PARADIGMSOF GERMAN FEDERALISM}

We know that many policy competences have been dispersed from central to regional levels of government over the last forty years (Hooghe, Marks and Schakel 2008). We know rather less about how far growth in regional competence brings with it differences in policy outcomes in different regional jurisdictions in the same state. There has been substantial work on this question in the mature federations of North America (e.g. Harrison 2006; Karch 2007). Such work is much less advanced in Europe, either in recently decentralised states or mature federations like Germany. This article attempts to establish a more systematic empirical basis for assessing the scope and significance of regional policy variation in Germany. It presents data on the extent of regional variation in policy outcomes in selected policy fields, and explores how far these variations can be explained by economic, institutional and party-political factors. ${ }^{1}$

Our finding is that - despite institutional structures that foster intense coordination between central and regional governments designed to secure (as the German constitution puts it) 'uniformity of living conditions', and despite apparent popular preferences for uniformity of policy outcomes- the extent of policy variation in Germany is greater than conventionally understood. There is, to adopt the language of this special issue, a greater depth of power dispersion in Germany than hitherto appreciated. We find that variation is driven not just by structural conditions beyond the control of governments, but also by politics. Parties, as Castles and McKinlay (1979) concluded in a different context over thirty years ago, do matter. These findings raise questions about the need for, and efficacy and limitations of, the mechanisms for statewide coordination between governments and for control over policy outcomes that are such a distinctive feature of German federalism. They challenge the conventional understanding of German federalism. This understanding is framed by a powerful intellectual paradigm that marks Germany out as an unusually unitarist - or controlled - form of federalism geared to uniformity of policy outcomes across the federation.

This paradigm was defined in early postwar assessments (Wheare 1953), and has periodically been asserted afresh, for example in Hesse's (1962) depiction of a 'unitary federal state', the assessments in the mid-1970s by Scharpf (1976) of entangled policymaking and Lehmbruch (1976) of the integration of party competition across the federal and Länder levels, Abromeit's (1992) analysis of post-unification continuities, and Scharpf's (2008) more recent reaffirmation of those continuities. It has survived the implementation of federalism reforms in 2006 (cf. Burkhart 2008; Scheller and Schmid 2008; Scharpf 2009) which were designed to 'disentangle' the federal and Land levels and increase Länder policy autonomy, extending the scope of power dispersion in Germany.

The conventional paradigm of German federalism focuses on:

- the functional distribution of responsibilities in which the federal level makes most laws and the Länder implement most of those laws;

- the close involvement of the Bundesrat (the federal parliamentary chamber comprised of Länder governments) in the federal legislative process; and

- the presumption that policy standards ('living conditions') experienced by all citizens should be 'uniform' irrespective of location.

This paradigm tends to discount the Länder as significant venues for policy-making, instead focusing on their 'entanglement' (Verflechtung) in politics at the federal level. It views politics in the Länder as a subordinate reflection of federal-level politics. Perhaps the pithiest summary of this paradigm is that by Scharpf (2008: 510):

The post-war German polity is a federal state with a unitary political culture ... there are no politically salient territorial cleavages ... and no popular demands for regional 
autonomy. Mass communication is dominated by nationwide media; political issues are defined and debated nationally; and public attention is focused on national parties even where they compete for office in the Länder. By contrast, the political salience of policy-making at the regional level is quite low, and the 16 Land elections have the character of 'second-order national elections' as parties tend to fight over national policy choices and about the performance of the national government.

The continued dominance of the uniformity paradigm is surprising given significant work over the last thirty-plus years focusing on innovation and difference in Länder politics (Mintzel 1977; Schmidt 1980; Benz 1985; Schmid 1990; Götz 1992; Sturm 1999a). More recently new research has pinpointed Land-by-Land variations in parties and party systems (Jun, Haas and Niedermayer 2008; Bräuninger and Debus 2012; Debus and Müller 2013; Müller 2013; Seher and Pappi 2011), coalition formation (Bräuninger and Debus 2008; Oberhofer and Sturm 2010), voting behaviour (Hough and Jeffery 2003; Völkl et al. 2008), institutions of government (Leunig 2006; Freitag and Vatter 2008), and public policy outcomes (Hildebrandt and Wolf 2008; Turner 2011; Tepe and Vanhuysse 2013).

There is now, in other words, a robust alternative paradigm of diversity and difference which in part recognises diversity that has always existed but rarely been recognised, and in part reflects the blindingly obvious: that after German unification in 1990 Germany exhibits much wider regional disparities on most significant socio-economic and political indicators than before 1990 (Benz 1999; Auel 2010; Jeffery and Rowe 2014). Even if a 'uniformity' of living conditions had once been possible - which is doubtful - it is not now.

\section{EXPLORING VARIATION IN POLICY OUTCOMES}

This article uses data on the territorial diversity of policy outcomes in Germany both to challenge the residual imagery of uniformity, but also to deepen the alternative understanding signalled by recent emphasis on diversity and difference. To put it in the terms of this special issue: there has long been a normative assumption in work on German federalism (and perhaps also in the way this special issue assumes that central governments should seek to coordinate and control their former competences as they disperse to other levels of government?) that federal coordination of governmental activity and control over policy outcomes is right, and better than the alternative of regional variation. As Sturm (1999b: 85) once put it 'regional diversity seemed to be something obsolete, which had to be overcome'. But why should not regional governments in Germany also be able to deliver 'right' and - or perhaps even 'better' - outcomes for citizens? Our aim is to open up a research agenda on how far (and why) the German federal system, as well as being a locus of policy entanglement in federal policy-making, is also a locus for distinctive policies in the Länder. We deliberately stress 'as well as' and 'also'; our aim is not to dismiss understandings of German federalism as the coordinated pursuit of uniform living conditions, but to reveal other facets of German federalism that at the same time foster diversity of living conditions. Insofar as such other facets are significant - or, given conditions since 1990, inevitable -questions open up about how far federal institutions should coordinate and control competences exercised by Länder governments. We return to this point at the end of the article.

We focus on an illustrative set of policy outcome indicators that reveal significant differences across the Länder. Our aim is both to document these differences - as such empirical work has rarely been done in any systematic way in the German case - but also to begin to explain why those differences occur. We recognise that policy outcomes are not simply the result of what governments do, but are also affected by many other factors. We attempt to capture at least some of these factors in the explanatory models presented later in 
this article and in the associated online appendices. Our focus on outcomes (rather than outputs like decisions on public spending on particular policies) is deliberate, because regional variation in policy outcomes jars with one aspect of the uniformity paradigm that remains largely unchallenged: the German public's strong expectations of uniformity of outcomes. Recent work on public attitudes on German federalism has revealed a striking paradox: citizens combine a 'pronounced preference for a greater role of regional institutions in policy-making' alongside generally overwhelming preferences for statewide uniformity of policy outcomes (Oberhofer et al. 2013: 104-6). Citizens appear to want the Länder to do more, but not to do it differently. With this paradox in mind, building a clearer understanding of policy difference, and the role of Länder governments in producing it, appears important in establishing a more nuanced understanding of the way the German federal system and its mechanisms of coordination and control operate.

We present below data on the extent of policy difference in the Länder in:

- prison occupancy rates ${ }^{2}$;

- $\quad$ salary levels for public servants (Beamte) $)^{3}$;

- naturalisation rates ${ }^{4}$; and

- university enrolment rates ${ }^{5}$

These four areas were chosen for two reasons. The first was to cover areas in which the depth of Länder competence differs, distinguishing fields under their own legislative responsibility from others in which they implement federal law with administrative discretion. For example, naturalisation is regulated by federal law, but is applied in the Länder with discretion exercised by Länder and local governments, including the length of the naturalisation process, the requirements for information in support of the application, the atmosphere (positive or hostile) created amongst officialdom, and also legal interpretation (Thränhardt, 2008). By contrast, secondary education (of which university enrolment is an outcome) has always been an exclusive legislative responsibility of the Länder. It might be expected that there would be more regional variations in outcomes where the Länder have autonomous legislative competences, rather than where they act as venues of implementation.

Second, we chose two areas in which the Länder received fuller competences following the 2006 federalism reforms. We would expect to see more variation following reform than before. Prior to 2006, prison law was decided at the federal level, with the Länder responsible for the implementation. In 2006 the Länder received full legislative responsibility for prisons- and quickly made use of this competence with new divergences in the aims of punishment, cell size, entitlement to therapy, the role of work in prisons, and rules on remand (Ostendorf 2012). Additionally, pay for public servants known as Beamte hitherto determined by federal law, albeit with some variations possible from 2004 onwards became an exclusive competence of the Länder as a result of the 2006 federalism reforms.

In the terms of this special issue, then, we have one area of policy which sees 'delegation' (naturalisation), and three which are examples of 'transfer' of power, of which one (university enrolment) has consistently been a Land competence, while two have seen a recent shift into Land competence (Beamte pay, and prisons). In the case of prisons, because earlier responsibility for policy implementation lay with the Länder, there has been a shift from 'delegation' to 'transfer', while Beamte pay shifted directly from central control to 'transfer'.

Table 1: Indicators of Policy Variation

\begin{tabular}{lrrrrr} 
& \multicolumn{2}{c}{ Standard } & & & \\
& Mean & Deviation & Minimum & Maximum & N \\
\hline Prison Occupancy Rate & 0.92 & 0.10 & 0.60 & 1.19 & 160 \\
Beamte Pay Level & 1651.10 & 107.15 & 1464.89 & 1965.27 & 160
\end{tabular}




\begin{tabular}{lrrrrr} 
Naturalisation Rate & 1.43 & 0.57 & 0.41 & 3.08 & 128 \\
University Enrolment Rate & 75.50 & 7.03 & 60.30 & 93.70 & 128 \\
\hline
\end{tabular}

Table 1 summarises the extent of variation of these indicators across the Länder; Figures 1 and 2 show variation by Land over time, and by year. Prison occupancy data run from 2001-10 and are measured as the number of prisoners relative to prison capacity. To an extent prison occupancy is determined by longer term issues about the building of prisons and patterns of sentencing; but Figures 1 and, especially, 2 reveal substantial short-term variation in occupancy that would appear not simply to reflect longer term infrastructure decisions or sentencing cultures. The lowest occupancy rate across this period was $60.1 \%$ in Hamburg in 2008 and the highest was 119\% in Thüringen in 2005.

The Beamte salary data (in Euros/month) are for level A5-1 and run from 2003-12. ${ }^{6}$ Pay and bonuses were set uniformly until 2003. From 2004, the Länder could determine Christmas bonuses and holiday pay. In 2006 complete control over pay levels shifted to the Länder. In 2012 pay levels ranged from 1672.80 Euros/month in Berlin to 1965.27 in Hamburg. Naturalisation rate data run from 2003-10 and are measured as the proportion of the foreign population that was naturalised in each Land in a given year. The lowest rate was in Saxony in 2004 at $0.41 \%$ and the highest in Schleswig-Holstein in 2004 at 3.08\%. University enrolment data (the proportion of eligible students enrolling in university), run from 2001-10 with data unavailable for 2007 and 2009. The lowest enrolment rate was in North Rhine-Westphalia in 2006 at $60.3 \%$ of eligible students and the highest in Berlin in 2004 at $93.7 \%$.

Figure 1 provides a visual display of variation within and across the Länder during the time periods examined. It shows significant variation in outcomes between the Länder both in areas of legislative competence, and those where the Länder have implementation responsibilities. For example, Brandenburg and Schleswig-Holstein are at two ends of a wide extent of variation in naturalisation rates (Figure 1a). There is a similar picture on prison occupancy (Figure 1b) and university enrolment (Figure 1d). While most of the Länder share similar data values at the low end of Beamte salaries (Figure 1c), this is a product of earlier part of the time period when the federal government set pay and bonus levels. The box plots in Figure 1 demonstrate that variation is not solely a product of differences between the Länder, but also of variation within each Land over time.

Figure 2 presents the variation for each policy outcome over time. The variation of naturalisation rates is fairly consistent from 2003-06 with a slightly smaller spread of variation from 2007-10 (Figure 2a). Given this is an area with a standard federal legislative framework, the considerable extent of variation suggests that significant policy discretion is applied in the Länder at the implementation stage. While prison occupancy rates show a similar level of variation over time, median values shift noticeably from year-to-year (Figure 2b). Each year some Länder have prisons below full capacity while others exceed capacity. The box plot in Figure 1b shows that almost all of the Länder had periods both under and over capacity, suggesting that short-term factors, and not just long-term infrastructure issues, impact on occupancy. There is some indication that occupancy rates have decreased a little since the 2006 reforms, though change is not yet pronounced. As Beamte salaries transferred from federal to Länder legislative competence, variations begin to appear, though it is not until 2008 that these become significant. University enrolment rates also vary significantly over time (Figure 2d). While both the average enrolment rate and extent of variation have decreased over time, in 2010 there were still noticeable differences in enrolment rates ranging from a low of $61 \%$ in Thuringia to $84 \%$ in Bavaria.

In summary, there are clear and considerable differences present for each indicator, both in transferred and delegated competences, and with emerging signs that reforms in 2006 
have opened up scope for further variation. This in itself is a notable observation given - as was mentioned above - that discussion of such Land-by-Land difference is generally absent in work within the conventional paradigm of German federalism. 
Figure 1: Variation across the Länder, Over Time for Policy Outcomes
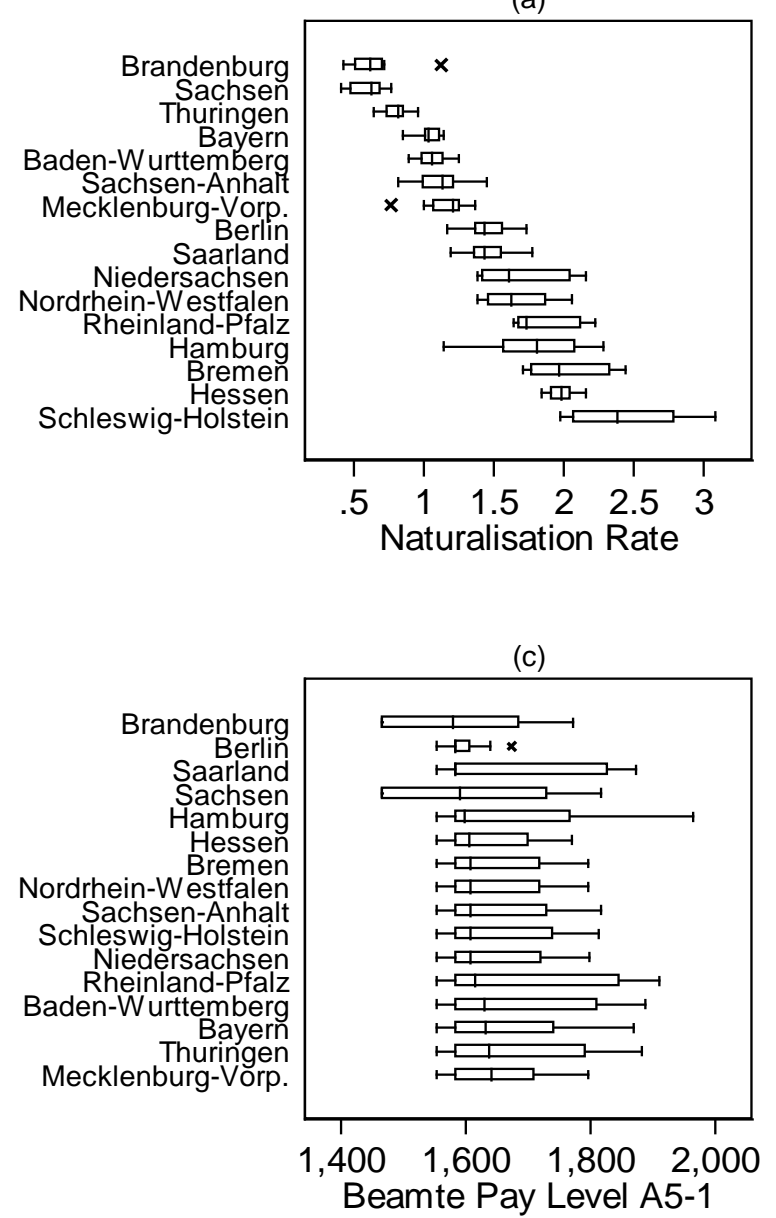

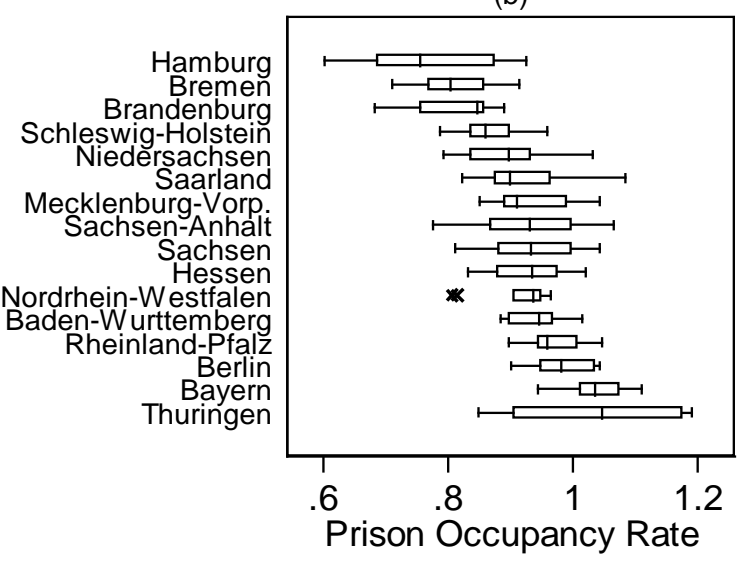

(d)

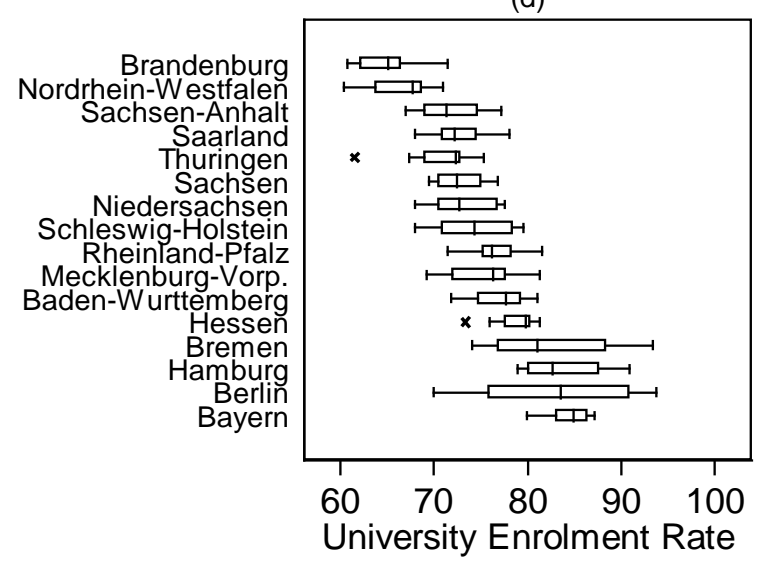


Figure 2: Variation over Time for Policy Outcomes
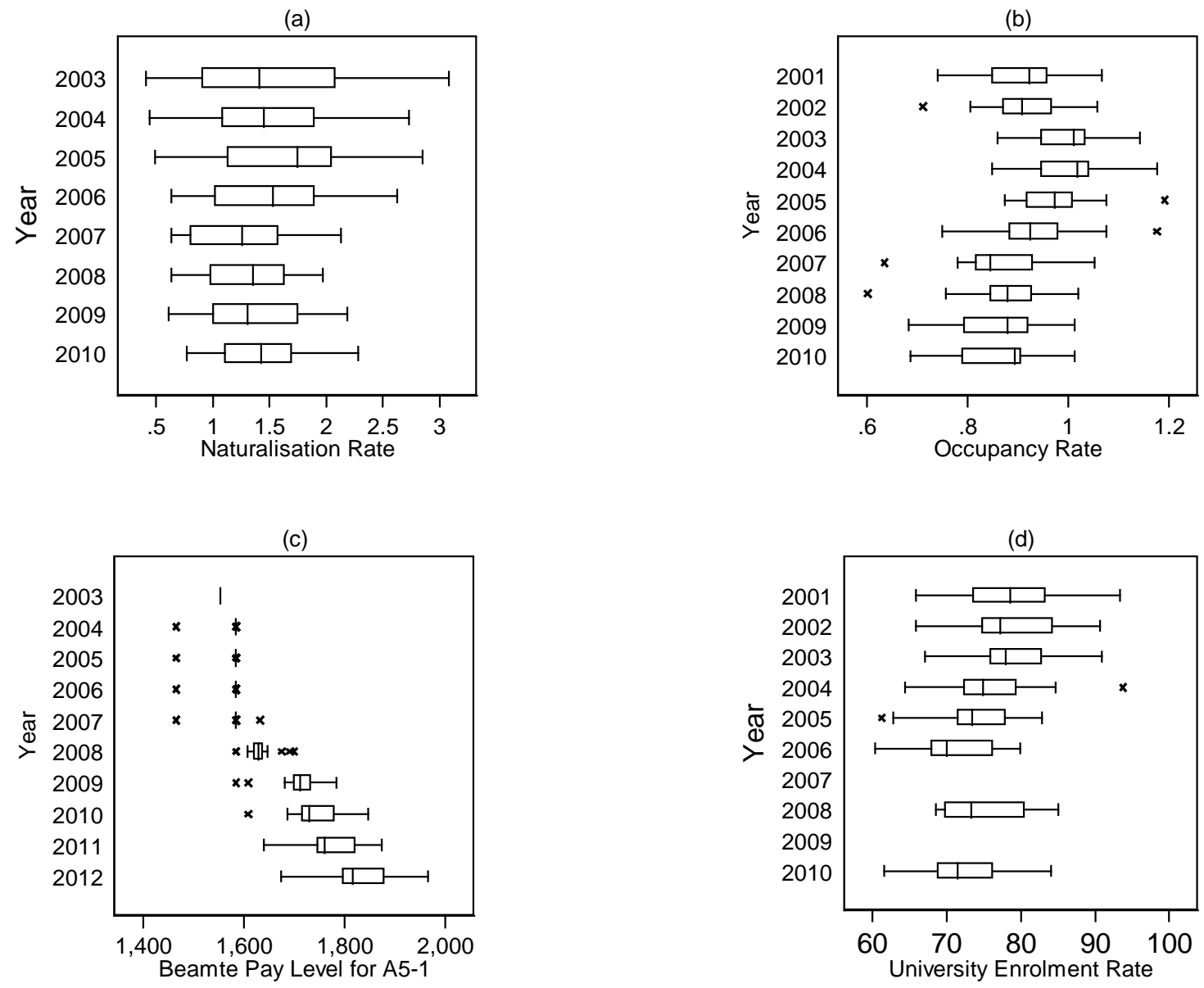


\section{EXPLAINING VARIATION: THEORY AND HYPOTHESES}

Our aim is not simply to document, but to begin to explain policy variation. Regional policy variation is not a field with a rich theoretical grounding. There is as yet little work on policy variation in German federalism, and much of what exists is case study work on one policy area with little commonality (and comparability) of approach across different areas. ${ }^{7}$ As a result - and with the notable exception of the pioneering but subsequently largely neglected analysis of Manfred Schmidt (1980) - there are no obvious theoretical models in the German federalism literature that might have application across a range of policy fields. Significantly Schmidt drew heavily on comparative work on welfare states and on patterns of policy variation within the US which took the US states as units of analysis. Like Schmidt we look to ideas in wider literatures that might be applied to regional policy variation in Germany, identifying connections with recent work on Germany which suggest they can usefully be applied in the German case. In such literatures - comparing across states, and comparing federal units within states - three concepts consistently (Myles and Quandango 2002; Pierson 1991) reoccur as explanations for policy variation: socio-economic context, partisan politics and the institutional features of the political system.

Below we suggest ways of operationalising these concepts in order then to build a parsimonious explanatory model that explores the association of these variables relative to variation in policy outcome indicators. We recognise that three independent variables cannot establish a comprehensive explanatory model. So we present a more fully specified model with controls in Appendix A in the online materials associated with this article. As the substantive implications of both models are very similar, we focus, for reasons of space, on the parsimonious model. We recognise that even the more fully specified model cannot capture all the contextual variables which impact on outcomes in each of our four fields. Nonetheless these simple models raise significant questions about the dominant understanding of German federalism.

The first prompt we take from the comparative literature concerns socio-economic context. Following a functionalist argument, policies of any type are the product of economic resources and competing demands for those resources. Various socio-economic factors are said to influence how governments prioritize policy areas, including wealth, unemployment, and the size of dependent populations. ${ }^{8}$ Comparative studies of policy choices across nationstates have shown that levels of wealth impact the balance between 'core' public goods like defence and public order and policies with more selective outcomes, including many of the features of contemporary welfare states (see e.g. Huber and Stephens 1993, 2001; Crepaz, 1998; Milesi-Ferretti et al. 2002; Bräuninger 2005; Iversen and Soskice 2006; Brooks and Manza 2007; Müller 2009). In analogy to this work, and echoing Wolf and Hildebrandt's (2008) findings from their recent collection of sectoral analyses of policy variation in the Länder, we expect the particular socio-economic context facing a Land to condition its policy choices and outcomes. In the model below we use real Gross Domestic Product per capita (GDP/capita), measured in $€ 10,000 / c a p i t a$, to capture socio-economic context. Our general expectation is that greater GDP/capita will enable greater focus on policies with targeted goods benefiting particular social groups.

A second concept commonly deployed in comparative analyses is the institutional context in which policy decisions are made and implemented. Different states have different institutional designs. Institutional structures may introduce greater or fewer actors into the decision-making process and affect policy outcomes. As more actors enter the decision making process, a greater need for negotiation is required to pass and implement legislation where each actor attempts to secure benefits for their particular constituency. Institutions that introduce a higher number of actors into the decision making process are frequently referred 
to as veto players, veto points, or institutions increasing policy resoluteness (Tsebelis 1995; Immergut 1990; Cox and McCubbins 2001; Wagschal and Welzelburger 2009). Recent work has shown that there are significant variations in institutional structure in the Länder, not least in Freitag and Vatter's (2008) adaptation of Lijphart's typology of democratic systems (1984, 1999). Following approaches similar to those of Huber and Stephens $(1993,2001)$ and Brooks and Manza (2007) we have developed an additive index which aggregates the number of institutional characteristics that create veto-playing opportunities in the German Länder ranging from zero (none of the characteristics) to five (all of them: Pure Proportional Representation, Effective Number of Parties greater than two, minimum winning coalition government, Sainte- Laguë remainder rule, open party lists). Details on how the index is created are available in Appendix B in the online materials. The general expectation is that more institutional constraints focus policy agendas on the needs and interests of particular groups in society.

The third independent variable concerns the role of party politics on policy, again echoing a long-standing theme in comparative analysis: parties matter (Blais 1993; Schmidt 1996; Castles 1998). We expect election outcomes (i.e., the particular party-political composition of Land parliaments), to impact public policy outcomes, as was Schmidt's (1980) main finding decades ago and as others (Turner 2011; Bräuninger and Debus 2012; Tepe and Vanhuysse 2013) have recently reiterated. Our measure is the number of seats held in each Land legislature each year by centre-left/left wing parties (SPD, Greens and PDS/Left), following similar approaches in the welfare literature (Huber and Stephens 2001; Iversen and Soskice 2006; Brooks and Manza 2007) and recent work on Germany (Debus, Knill and Tosun 2013). ${ }^{9}$ Our general expectation - consistent with comparative work on welfare states and in the Comparative Manifestos Project - is that the stronger the presence of left parties, the greater the policy focus on particular group interests (while parties on the right focus on more traditional and broader agendas such as defence and public order - e.g. Tepe and Vanhuysse 2013). ${ }^{10}$

\section{Table 2: Independent Variables}

\begin{tabular}{lrrrrr} 
& \multicolumn{2}{c}{ Standard } & & & \\
& Mean & Deviation & Minimum & Maximum & \multicolumn{1}{c}{ N } \\
\hline Real GDP/Capita & 2.67 & 0.75 & 1.77 & 4.73 & 160 \\
Institutional Constraint & 1.64 & 1.17 & 0.00 & 5.00 & 160 \\
Strength of Left Parties & 48.85 & 9.44 & 24.85 & 72.00 & 160 \\
\hline
\end{tabular}

Note: Data has been collected for the period 1999-2010.

The independent variables present a mix of structural conditions (socio-economic context, institutional structures) largely beyond the short term influence of governments, and of shorter term agency (decisions by regional electorates which periodically renew the partisan configuration of regional parliaments). Table 2 shows that each variable differs considerably across the Länder over the period studied. Most of the variation in real GDP/capita exists as differences between the Länder. Such variations are now much wider than they were before German unification in 1990. But each of the Länder also demonstrates variation in real GDP/capita over time. Our institutional scale reflects the differences in institutional structure inherent in a federal system built 'from the bottom up' as the Länder were established in the late 1940s. But it also includes components that change with each election. The strength of left parties reflects the choices made by voters in Land-level elections. Some Länder have been long-term strongholds of the left (or of the right, with consequent lower representation of the left); nonetheless there remain significant within-Land variations from election to election. Variation exists not only between each of the Länder for 
each variable but also within each Land over time, as is shown graphically in Appendix C online.

Based on the general expectations found in the literature we can generate more explicit hypotheses regarding our independent variables and policy outcomes. Each of the policy outcomes selected engages specific social interests within each Land. While public order and safety is a general concern for the population at large, the severity of penalties and prison environments affect only a portion of society. While education policies have a general resonance, those aspects affecting higher education target a smaller portion of the general public who have the inclination and ability to proceed to university. Migrants seeking citizenship are a small group with very specific concerns. Beamte pay levels reflect the interests of a narrow group, providing little direct benefit for the wider population. Overall, we expect higher values for the three variables of socio-economic context, left parties in office, and institutional design to be associated with higher values for university enrolment, naturalisation rates, and Beamte pay, but with lower levels of prison occupancy rates.

a) Socio-economic context - Stronger economic performance enables a move beyond 'core' public goods to policy domains that target particular groups. With additional resources Land governments can provide alternative methods of incarceration to address the concerns of prison advocacy groups, allow more immigrants to be naturalised, expand access to higher education, and provide more incentives for Beamte through better wages.

b) Institutional context - The greater the number of institutional access/veto points in a Land, the more opportunities groups have to capture the policy agenda and promote particular interests: advocacy groups promoting the rights of convicted criminals, immigrants, high school students seeking access to university, and government employees.

c) Left parties -As parties with similar ideological leanings gain control in governments they are in a better position to promote their party platforms. We expect that greater strength of left-leaning parties will be associated with lower prison occupancy and higher naturalisation rates (with left parties conventionally 'softer' on crime and more open to immigration), widening access to higher education, and higher pay rates as they are amenable to claims of highly unionised employees (Beamte).

\section{RESULTS}

Table 3 presents the results of standard OLS regression models with panel-corrected errors which explore the impact of our independent variables on each policy outcome indicator. ${ }^{11}$ In addition we have included a year variable to help us to track any general patterns of change over time not captured by the other variables in the model. Each independent variable is lagged by two years to allow it time to influence policy outcomes. ${ }^{12}$

The results show, with two exceptions, that the independent variables have a statistically significant association at least at the 0.05 level. Higher levels of GDP/capita are associated with lower prison occupancy rates, lower levels of Beamte pay, and higher naturalisation and university enrolment rates. The findings on GDP/capita lend support to our previously outlined expectations for three of our four indicators (prison occupancy, naturalisation rates, and university enrolment). However, our parsimonious model in Table 3 for Beamte pay runs counter to our expectations, though this appears to be an artefact of limited data availability since the reforms went into place. ${ }^{13}$

In our models institutional constraints have a statistically significant association with two of our selected outcomes. More institutional constraints are associated with higher naturalisation rates and higher levels of public sector pay. However, institutional constraints 
did not have a statistically significant association with prison occupancy or university enrolment.

Finally, greater electoral strength of left-leaning parties is associated with lower prison occupancy, Beamte pay and university enrolment, and higher naturalisation rates. Although we hypothesised that parties of the left would support pay claims of Beamte, it may be they are in fact less open to competing on pay, and choose to prioritise other areas of expenditure. For example, in interviews with Beamte representatives we heard that, because Beamte are banned from striking they have limited bargaining power, and are seen as a more conservative part of the public sector, left parties in government may choose not to promote their interests. ${ }^{14}$ The finding that parties of the left are associated with lower levels of higher education enrolment, while perhaps counter-intuitive, finds an echo in recent studies which find education expenditure is more of a priority for the right in the German Länder (Wolf 2009; Rauh et al. 2011). It may be that, as in other areas (e.g. Tepe and Vanhuysse 2013), inherited assumptions about the priorities of left parties require revision.

The year variable indicates that all else being held constant there are, over time, decreasing prison occupancy, naturalisation and university enrolment rates in the period under examination, but increases in Beamte pay.

\section{Table 3: What Causes Variation?}

\begin{tabular}{|c|c|c|c|c|}
\hline & $\begin{array}{c}\text { Prison } \\
\text { Occupancy Rates }\end{array}$ & $\begin{array}{c}\text { Naturalisation } \\
\text { Rates }\end{array}$ & $\begin{array}{c}\text { Beamte } \\
\text { Pay Level }\end{array}$ & $\begin{array}{l}\text { University } \\
\text { Enrolment }\end{array}$ \\
\hline & $\begin{array}{l}\text { Coefficient } \\
\text { (s.e.) }\end{array}$ & $\begin{array}{l}\text { Coefficient } \\
\text { (s.e.) }\end{array}$ & $\begin{array}{c}\text { Coefficient } \\
\text { (s.e.) }\end{array}$ & $\begin{array}{c}\text { Coefficient } \\
\text { (s.e.) }\end{array}$ \\
\hline & P-value & P-value & P-value & P-value \\
\hline \multirow[t]{3}{*}{ GDP/Capita } & $-0.057 * * *$ & $0.161 * * *$ & $-16.114^{* *}$ & $4.657 * * *$ \\
\hline & $(0.010)$ & $(0.045)$ & $(8.056)$ & $(0.839)$ \\
\hline & 0.000 & 0.000 & 0.023 & 0.000 \\
\hline \multirow[t]{3}{*}{ Left Parties } & $-0.005^{* * *}$ & $0.007^{* *}$ & $-1.240 * *$ & $-0.059 * *$ \\
\hline & $(0.0004)$ & $(0.003)$ & $(0.456)$ & $(0.030)$ \\
\hline & 0.000 & 0.004 & 0.004 & 0.050 \\
\hline \multirow[t]{3}{*}{ Institutions } & 0.002 & $0.144 * * *$ & $20.255^{* * *}$ & 0.313 \\
\hline & (0.006) & $(0.036)$ & (5.291) & (0.599) \\
\hline & 0.733 & 0.000 & 0.000 & 0.601 \\
\hline \multirow[t]{3}{*}{ Year† } & $-0.012 * *$ & $-0.035 * *$ & $30.901 * * *$ & $-0.831 * * *$ \\
\hline & $(0.004)$ & $(0.013)$ & (3.654) & $(0.209)$ \\
\hline & 0.003 & 0.008 & 0.000 & 0.000 \\
\hline $\mathrm{R}^{2}$ & 0.3764 & 0.2712 & 0.7500 & 0.4109 \\
\hline Adj. $R^{2}$ & 0.3603 & 0.2475 & 0.7435 & 0.3918 \\
\hline $\mathrm{N}$ & 160 & 128 & 160 & 128 \\
\hline
\end{tabular}

Though these are deliberately simple models the $\mathrm{R}^{2}$ figures on prison occupancy and especially public service pay explain relatively high (and on prisons and naturalisation significant) proportions of the variation in our policy outcome indicators. Most of the relationships between the independent and dependent variables confirm our expectations. Some do not. Nonetheless, our findings offer significant challenge to conventional understandings of German federalism. 


\section{CONCLUSION}

In the areas we have explored here policy outcomes in the Länder are more diverse than is generally recognised. Throwing light onto this variation and building explanations for it allows us to return to the competing paradigms of German federalism discussed at the outset and themes of power dispersion, coordination and control. Table 3 suggests that much of the variation we have identified is 'structural' in its causes, reflecting (clearly) differences in economic performance, and (partly) differences in institutional configuration in the Länder. Insofar as variation is structural, it need not challenge the conventional view of German federalism as a highly focused effort to achieve as common a set of outcomes across Germany as a finely tuned intergovernmental coordination system can manage. That system might be seen to be falling short and require remedy, or alternatively to need to face up to the immense structural differences post-unification and set its sights lower. But German federalism would remain within its conventional paradigm, geared to coping with the power dispersion inherent in the distribution of powers in a federal system through intense coordination among Germany's governments.

However, the data presented here also suggests that a significant part of the variation reflects agency: the collective preferences of Länder electorates as mediated through the parties they elect. Insofar as variation reflects agency, it challenges the conventional view of German federalism, and resonates with the alternative paradigm of innovation and diversity that sees the Länder making (unexpectedly vigorous) use of dispersed powers and - as in the 2006 reforms - arguing for more. In this light the conventional paradigm of German federalism as a highly integrated system geared to broadly common outcomes appears inappropriate or at least insufficient. Coping with power dispersion appears much more to be about recognising (and embracing?) more fully the depth and scope of autonomous decisionmaking responsibilities in the Länder and understanding better the costs and benefits of autonomy, limiting the former and maximising the latter. In that sense that the Länder may be, as we suggested at the outset, as appropriate or perhaps 'better' platforms for delivering public policies as the highly coordinated, national politics of German federalism. ${ }^{15}$

We do not though propose an either-or contest between the conventional paradigm of uniformity, coordination and control and the alternative paradigm of diversity, variation and autonomy. Just as we are clear from the analysis here that German federalism is not entirely consumed in a struggle to coordinate away the effects of structural differences, we are clear too that it is not entirely geared to a new practice of boundless competition and innovation. As research on policy variation unfolds, our expectation is that we will find a co-existence of two federalisms, in which different policy areas conform more to the one paradigm than the other, and different Länder align themselves to the one paradigm over the other. What is striking in the German federalism literature hitherto is that the (dominant) uniformity paradigm and the (challenger) diversity paradigm barely engage with one another, but remain bound up in disciplinary and generational differences. Our findings may offer a bridge between these camps and open up a route towards a more differentiated and, we suspect, a more accurate framing of German federalism as both highly coordinated and increasingly diverse. 


\section{NOTES}

1. This article reports on a German Academic Exchange Service (DAAD)-funded research project on 'Reframing German Federalism.' We are grateful to the DAAD for its support.

2. BKA-Statistik. Polizeiliche Kriminalstatistik Bundesrepublik Deutschland. Annual Reports 2001-10.

3. Öffentlicher Dienst.info http://oeffentlicher-dienst.info/beamte/. Accessed 3 June 2013.

4. Statistisches Bundesamt. 2011. "Bevölkerung und Erwerbstätigkeit.” https://www.destatis.de/DE/Publikationen/Thematisch/Bevoelkerung/MigrationIntegr ation/Migrationshintergrund2010220107004.pdf? blob=publicationFile. Accessed 3 June 2013.

5. Bildungsbericht. Bildung in Deutschland 2012. Table F1-1A: Übergangsquoten in die Hochschule 1980 bis 2010 nach Ländern, Geschlecht, Art der Hochschulreife und Migrationshintergrund (in \%). www.bildungsbericht.de/daten2012/f1_2012.xls . Accessed 3 June 2013.

6. This pay level was taken as an example to highlight variation in pay rates. Other more senior levels of seniority were examined and produced similar results.

7. See for example the contributions to Hildebrandt and Wolf (2008).

8. In the fuller model in Appendix A in addition to GDP/capita we include unemployment rates, size of the youth and elderly populations, and Länder fiscal equalization (in Euros and proportion given/received).

9. In Appendix A we also include other measures to represent the preferences of citizens including an east-west dummy variable, the proportion of Catholics in each Länder as a proxy for social conservatism, and whether the Land Government was controlled by a Left party.

10. Pappi and Seher (2009) examined left/right preferences between parties by policy area in Germany and produced similar results to the Comparative Manifestos Project (CMP), suggesting that at least in the fields of social affairs, foreign affairs, education, and the interior and justice there are clear left/right divides consistent with the operationalization used here. Additionally, the literature suggests there is not a large difference between policy positions for state versus national parties Müller (2012). Furthermore, if we used the CMP data to assign left/right party leanings, in order to create a single variable representing the partisanship of the government we would have weighted the proportion of seats held by each party by their party manifesto score to create an overall score. This score would likely produce similar results to the aggregate proportion of seats, as the left parties take on positive values in the manifesto dataset and the right parties take on negative values.

11. Lags for prior year policy outcomes were omitted from the model for two reasons. First, the lag would create models that would allow us to compare differences in the change of each outcome between the Länder, while our interest is in comparing differences between the levels. Second the use of lags would increase predictive power, but as both the independent and dependent variables are slow to change over time, the inclusion of the lags would be highly collinear with the independent variables in the model making it difficult to determine the relationship between potential sources of variation and the outcomes.

12. The lag structure follows that proposed by Klingemann et al. (1994) where one year is required to influence the policy process and another is required for the changes to policy to take effect. However, similar results are achieved when a one year lag structure is used. 
13. The potentially counter-intuitive finding for the relationship between real GDP/Capita and Beamte salaries can be accounted for by two key points. First the newly introduced reforms have only recently begun to allow for variation in pay relative to wealth. For over half the years we examine, regardless of wealth, pay levels were relatively uniform, limiting the variation present between the two variables. If we examine from 2008 forward there is a more positive association between wealth and pay, however, it is not strong enough to overcome the pull of the first half of the sample of data at this time and prevents a positive correlation from appearing. Additionally the strength of left parties in office and institutional constraints has a high degree of multicollinearity with GDP/capita making it difficult to parse out the association between GDP/Capita and Beamte salaries.

14. Interviews with Land chairs of German Beamte Confederation, $6^{\text {th }}$ Nov 2012, $3^{\text {rd }}$ Dec 2012.

15. In qualitative research conducted as part of this project it does not appear, for example, that new competences won in the 2006 reforms have led to any reduction in policy standards, as many had feared. If anything, the opposite appears to be the case (Rowe and Turner 2013). 


\section{REFERENCES}

Abromeit, H. (1992): Der verkappte Einheitsstaat (Opladen: Leske und Budrich)

Auel, K. (2010) 'Between Reformstau and Länder Strangulation? German Co-operative Federalism Reconsidered’, Regional \& Federal Studies. 20(2): pp. 229-49.

Benz, A.(1985): Föderalismus als dynamisches System. Zentralisierung und Dezentralisierung im föderativen Staat (Opladen: Leske und Budrich).

Benz, A. (1999) 'From Unitary to Asymmetric Federalism in Germany: Taking Stock after 50 Years’, Publius: The Journal of Federalism. 29(4):pp55-78.

Blais, A. et al (1993), 'Do Parties make a Difference? Parties and the Size of Government in Liberal Democracies', American Journal of Political Science, 37:1

Bräuninger, T. (2005) 'A Partisan Model of Government Expenditure’, Public Choice. 125(3/4):409-29.

Bräuninger, T. and M. Debus (2008) 'Der Einfluss von Koalitionsaussagen, programmatischen Standpunkten und der Bundespolitik auf die Regierungsbildung in den deutschen Ländern', Politische Vierteljahresschrift. 49(2): pp.309-38.

Bräuninger, T. and Debus, M. (2012) Parteienwettbewerb in den deutschen Bundesländern, Stuttgart: VS Verlag.

Brooks, C. and Manza, J. (2007) Why Welfare States Persist: The Importance of Public Opinion in Democracies, The University of Chicago Press Books.

Burkhart, S. (2008) Blockierte Politik. Ursachen und Folgen von ,Divided Government‘ in Deutschland, Frankfurt: Campus.

Castles, F.G. and R.D. McKinlay (1979) 'Public Welfare Provision, Scandinavia, and the Sheer Futility of the Sociological Approach to Politics', British Journal of Political Science. 9(2): pp.157-71.

Castles, F. (1998) Comparative Public Policy: Patterns of Post-war Transformation, Cheltenham: Edward Elgar.

Cox, G.W. and McCubbins M.D. (2001) 'The Institutional Determinants of Economic Policy Outcomes' in S. Haggard and M.D. McCubbines (eds). Presidents, Parliaments, and Policy, Cambridge University Press, pp.1-20.

Crepaz, M.L. (1998) 'Inclusion versus Exclusion: Political Institutions and Welfare Expenditures’, Comparative Politics. 31(1):61-80.

Debus, M. and J. Müller. (2013) 'The Programmatic Development of CDU and CSU since Reunification: Incentives and Constraints for Changing Policy Positions in the German Multi-Level System’, German Politics. 22(1-2):pp151-71.

Debus M., C. Knill, and J. Tosun. (2013) 'Registration Fees for Same-Sex Unions, Local Party Politics and Societal Demand’, Local Government Studies. pp.1-21. 
Freitag, M. and Vatter, A. (2008) (eds.): Die Demokratien der deutschen Bundesländer: Politische Institutionen im Vergleich, Opladen: Barbara Budrich.

Götz, K. (1992) Intergovernmental Relations and State Government Discretion: The Case of Science and Technology Policy in Germany, Baden-Baden: Nomos.

Harrison, K. (2006) (Ed.): Racing to the bottom? Provincial Interdependence in the Canadian Federation (Vancouver: UBC Press).

Hesse, K. (1962) Der unitarische Bundesstaat, Karlsruhe: Müller.

Hildebrandt, A. and Wolf, F. (eds.) (2008) Die Politik der Bundesländer: Staatstätigkeit im Vergleich, Wiesbaden: VS Verlag.

Hooghe, L., G. Marks and A. Schakel (2008) 'Patterns of Regional Authority', Regional and Federal Studies. 18(2-3): pp167-81.

Hough, D. and Jeffery, C. (2003): 'Landtagswahlen: Bundestestwahlen oder Regionalwahlen', Zeitschrift fur Parlamentsfragen, 33(1): 49-66.

Huber, E. and Stephens, J.D. (1993) 'Political Parties and Public Pensions', Acta Sociologica 36(4):309-25.

Huber, E. and Stephens, J.D. (2001). Development and Crisis of the Welfare State: Parties and Policies in Global Markets, University of Chicago Press.

Immergut, E.M. (1990) 'Institutions, Veto Points, and Policy Results: A Comparative Analysis of Health Care’, Journal of Public Policy. 10(4):391-416.

Iversen, T. and D. Soskice. (2006) 'Electoral Institutions and the Politics of Coalitions: Why Some Democracies Redistribute More than Others', American Political Science Review. 100(2): pp. 165-81.

Jeffery, C. and Rowe, C. (2014, forthcoming) 'The Reform of German Federalism', in Padgett, S., Paterson, W. and Zohlnhoefer, R. (eds.) Developments in German Politics (4th edition), Basingstoke: Palgrave.

Jun, U., Haas, M., and Niedermayer, O. (Eds.) (2008) Parteien und Parteiensysteme in den deutschen Ländern, Wiesbaden: VS Verlag.

Karch, A. (2007) Democratic Laboratories. Policy Diffusion among the American States (Ann Arbor: University of Michigan Press).

Keating, M. (2009) 'Social Citizenship, Solidarity and Welfare in Regionalized and Plurinational States’, Citizenship Studies. 13(5):pp 501-13.

Klingemann, H.D., Hofferbert, R.I. and Budge, I. (1994) Parties, Policies, and Democracy, Boulder: Westview Press.

Landtag Rheinland-Pfalz (2007): Plenarprotokoll 15/33. Mainz: Landtag Rheinland-Pfalz. Lehmbruch, G. (1976) Parteienwettbewerb im Bundesstaat, Stuttgart: Kohlhammer. 
Leunig, S. (2006) Die Regierungssysteme der deutschen Länder im Vergleich, Opladen: Verlag Barbara Budrich.

Lijphart, A. (1984) Democracies. Patterns of Majoritarian and Consensus Government in Twenty-One Countries, New Haven: Yale University Press.

Lijphart, A. (1999) Patterns of Democracy. Government Forms and Performance in ThirtySix Countries, New Haven: Yale University Press.

Massicotte, L. (2003) 'To Create or to Copy? Electoral Systems in the German Länder’, German Politics. 12(1): pp.1-22.

Milesi-Ferretti, G., M., Perotti, R., and Rostagno, M. (2002) 'Electoral Systems and Public Spending', Quarterly Journal of Economics May:609-57.

Mintzel, A. (1977) Geschichte der CSU. Ein Überblick, Opladen: Leske und Budrich.

Müller, J. (2009) 'The Impact of the Socio-Economic Context on the Länder Parties' Policy Positions’, German Politics. 18(3): pp. 365-84.

Müller, J. (2013) 'On a Short Leash? Sub-National Party Positions between Regional Context and National Party Unity’, Journal of Elections, Public Opinion and Parties 23(2): pp17799.

Myles, J. and J.S. Quandango. (2002) 'Political Theory of the Welfare State', Social Service Review. 76(1):pp. 34-57.

Oberhofer, J. and Sturm, R. (eds.) (2010) Koalitionsregierungen in den Ländern und Parteienwettbewerb, München: Allitera.

Oberhofer et al. (2013) 'Regional Citizenship in Germany: Solidarity and Participation in a Unitary Federal State’, in Henderson, Ailsa, Jeffery, Charlie and Wincott, Daniel (eds), Citizenship after the Nation-State (Basingstoke: Palgrave Macmillan), pp. 80-108.

Ostendorf, H. (ed.) (2012, $2^{\text {nd }}$ edition): Jugendstafvollzugsrecht: Kommentierte Darstellung der einzelnen Jugendstrafvollzugsgesetze, Baden-Baden: Nomos.

Pappi, F.U. and N.M. Seher. (2009) 'Party Election Programmes, Signalling Politics and Salience of Specific Policy Domains: The German Parties from 1990 to 2005’, German Politics. 18(3): pp. 403-25.

Pierson, C. (1991) Beyond the Welfare State? The new Poitical Economy of Welfare (Cambridge: Polity).

Rauh C., A. Kirchner and R. Kappe (2011) 'Political Parties and Higher Education Spending: Who Favours Redistribution?’, West European Politics. 34(6): pp. 1185-1206.

Scharpf, F.W. (2008) 'Community, Diversity and Autonomy: The Challenges of Reforming German Federalism’, German Politics, 17(4):pp. 509 - 21.

Scharpf, Fritz W. (2009): Föderalismusreform. Kein Ausweg aus der Politikverflechtungsfalle?, Frankfurt: Campus. 
Scharpf, F.W. et al. (1976) Politikverflechtung. Theorie und Empiriedes kooperativen Föderalismus in der Bundesrepublik, Kronberg: Scriptor.

Schmid, J. (1990) Die CDU. Organisationsstrukturen, Politiken und Funktionsweisen einer Partei im Föderalismus, Opladen: Leske \& Budrich.

Schmidt, M. (1980) CDU und SPD an der Regierung. Ein Vergleich ihrer Politik in den Ländern, Frankfurt/Main: Campus.

Schmidt, M. (1996), 'When Parties Matter: A Review of the Possibilities and Limits of Partisan Influence on Public Policy’, European Journal of Political Research 30:2.

Scheller, H. and Schmid, J. (eds.) (2008): Föderale Politikgestaltung im deutschen Bundesstaat. Variable Verflechtungsmuster in Politikfeldern, Baden-Baden: Nomos.

Seher, N.M. and F.U. Pappi. (2011) 'Politikfeldspezifische Positionen der Landesverbände der deutschen Parteien.’ MZES Working Paper Nr. 139. Mannheim: Mannheimer Zentrum für Europäische Sozialforschung.

Sturm, R. (1999a) 'Party Competition and the Federal System: The Lehmbruch Hypothesis Revisited’, in: Jeffery, Charlie (ed.), Recasting German Federalism. The Legacies of Unification, London: Pinter, pp. 197-216.

Sturm, R. (1999b) 'Der Föderalismus im Wandel. Kontinuita“tslinien und Reformbedarf', in Jesse, E. and Löw, K. (eds.), 50 Jahre Bundesrepublik Deutschland, Berlin: Duncker \& Humblot.

Tepe, M. and P. Vanhuysse. (2013) 'Parties, Unions, and Activiation Strategies: The ContextDependent Politics of Active Labor Market Policy Spending’, Political Studies (Forthcoming).

Thränhardt, D. (2008) Einbürgerung Rahmenbedingungen, Motive und Perspektiven des Erwerbs der deutschen Staatsangehörigkeit. (Bonn, Germany: Friedrich-EbertStiftung).

Tsebelis, G. (1995) 'Decision Making in Political Systems: Veto Players in Presidentialism, Parliamentarism, Multicameralism, and Multipartyism’, British Journal of Political Science 25:289-326.

Turner, E (2011):Political Parties and Public Policy in the German Länder: When Parties Matter, Basingstoke: Palgrave Macmillan.

Turner, E. and Rowe, C. (2013) 'Party Servants, Ideologues or Regional Representatives? The German Länder and the Reform of Federalism', West European Politics 6(2): pp. 382404.

Völkl, K. et al. (eds.) (2008) Wähler und Landtagswahlen in der Bundesrepublik Deutschland, Baden-Baden: Nomos.

Wagschal, U. and Wenzelburger, G. (2009): 'Determinanten der Haushaltskonsolidierung der Bundesländer 1992-2006‘, Zeitschrift für Vergleichende Politikwissenschaft, 3*(1): 33-58 
Wheare, K. (1953) Federal Government, $3^{\text {rd }}$ edition, Oxford: Oxford University Press.

Wolf, F. (2009) 'The Division of Labour in Education Funding: A Cross-

NationalComparison of Public and Private Education Expenditure in 28 OECD

Countries', Acta Politica 44:pp. 50-73.

Wolf, F. and Hildebrandt, A. (2008) 'Sechzehn Länder, sechzehn Felder: Erträge des Vergleichs', in Hildebrandt, A. and Wolf, F. (eds.) Die Politik der Bundesländer: Staatstätigkeit im Vergleich, Wiesbaden: VS Verlag. 
APPENDIX A: MODEL RESULTS FOR FULLER SPECIFICATION

\section{FIGURE A.1: Regression Model Results}

\begin{tabular}{|c|c|c|c|c|c|c|c|c|}
\hline & \multicolumn{2}{|c|}{$\begin{array}{c}\text { Prison Occupancy } \\
\text { Rates } \\
\end{array}$} & \multicolumn{2}{|c|}{ Naturalisation Rates } & \multicolumn{2}{|c|}{ Beamte Pay Level } & \multicolumn{2}{|c|}{ University Enrolment } \\
\hline & $\begin{array}{c}\text { Coefficient } \\
\text { (s.e.) }\end{array}$ & P-value & $\begin{array}{c}\text { Coefficient } \\
\text { (s.e.) }\end{array}$ & P-value & $\begin{array}{c}\text { Coefficient } \\
\text { (s.e.) }\end{array}$ & P-value & $\begin{array}{c}\text { Coefficient } \\
\text { (s.e.) }\end{array}$ & P-value \\
\hline Real GDP/Capita & $\begin{array}{l}-0.099 \\
(0.013)\end{array}$ & 0.000 & $\begin{array}{l}-0.487 \\
(0.130)\end{array}$ & 0.000 & $\begin{array}{l}-61.498 \\
(11.131)\end{array}$ & 0.000 & $\begin{array}{c}3.385 \\
(1.584)\end{array}$ & 0.012 \\
\hline Unemployment Rate & $\begin{array}{c}0.006 \\
(0.005)\end{array}$ & 0.100 & $\begin{array}{l}-0.028 \\
(0.013)\end{array}$ & 0.012 & $\begin{array}{l}-13.407 \\
(3.037)\end{array}$ & 0.000 & $\begin{array}{l}-0.450 \\
(0.296)\end{array}$ & 0.064 \\
\hline Fiscal Equalisation & $\begin{array}{l}-0.002 \\
(0.001)\end{array}$ & 0.000 & $\begin{array}{l}-0.007 \\
(0.004)\end{array}$ & 0.032 & $\begin{array}{l}-0.379 \\
(0.461)\end{array}$ & 0.206 & $\begin{array}{c}0.015 \\
(0.047)\end{array}$ & 0.378 \\
\hline Youth Population & $\begin{array}{l}-0.024 \\
(0.008)\end{array}$ & 0.002 & $\begin{array}{c}0.033 \\
(0.059)\end{array}$ & 0.289 & $\begin{array}{l}-9.283 \\
(4.289)\end{array}$ & 0.015 & $\begin{array}{l}-2.596 \\
(0.590)\end{array}$ & 0.000 \\
\hline Institutional Constraints & $\begin{array}{c}0.004 \\
(0.006)\end{array}$ & 0.260 & $\begin{array}{c}0.237 \\
(0.051)\end{array}$ & 0.000 & $\begin{array}{l}40.183 \\
(5.449)\end{array}$ & 0.000 & $\begin{array}{l}-0.873 \\
(0.624)\end{array}$ & 0.162 \\
\hline Leftist Parties in Office & $\begin{array}{l}-0.004 \\
(0.001)\end{array}$ & 0.000 & $\begin{array}{c}0.016 \\
(0.002)\end{array}$ & 0.000 & $\begin{array}{c}0.799 \\
(0.304)\end{array}$ & 0.005 & $\begin{array}{l}-0.118 \\
(0.042)\end{array}$ & 0.003 \\
\hline Catholic Population & $\begin{array}{c}0.001 \\
(0.001)\end{array}$ & 0.074 & $\begin{array}{l}-0.011 \\
(0.002)\end{array}$ & 0.000 & $\begin{array}{c}0.371 \\
(0.197)\end{array}$ & 0.030 & $\begin{array}{l}-0.089 \\
(0.018)\end{array}$ & 0.000 \\
\hline Eastern Länder & $\begin{array}{l}-0.149 \\
(0.029)\end{array}$ & 0.000 & $\begin{array}{l}-1.012 \\
(0.240)\end{array}$ & 0.000 & $\begin{array}{c}38.850 \\
(29.253)\end{array}$ & 0.092 & $\begin{array}{l}-10.447 \\
(3.246)\end{array}$ & 0.001 \\
\hline Year & $\begin{array}{l}-0.016 \\
(0.005)\end{array}$ & 0.002 & $\begin{array}{l}-0.038 \\
(0.018)\end{array}$ & 0.015 & $\begin{array}{l}26.256 \\
(3.149) \\
\end{array}$ & 0.000 & $\begin{array}{l}-1.521 \\
(0.270)\end{array}$ & 0.000 \\
\hline $\mathrm{R}^{2}$ & & 0.4566 & & 0.7022 & & 0.8423 & & 0.4984 \\
\hline
\end{tabular}


In order to control for other potential factors associated with the four policy outcomes examined in the paper, an alternative model specification was run including additional variables. In the parsimonious model specifications presented in Table 3, a single variable was used to capture the association between three separate concepts (socio-economic constraints, political preferences, and institutional designs) argued in the literature to be associated with policy decisions and outcomes. To include a more exhaustive list of socioeconomic factors the unemployment rate (Crepaz 1998; Huber and Stephens 2000, 2001; Bräuninger 2005; Iversen and Soskice 2006; Shelton 2007), the proportion of the population under the age of 15 (Huber and Stephens 2000, 2001; Chang 2008), and the proportion of Länder fiscal equalization that a Land gave or received was included. Data on all three variables was taken from the German Federal Statistics Office. The proportion of the population over the age of 65 and purchasing power parity was also included in an additional specification but were found to not have a statistically significant relationship with the outcomes under examination or to contribute to the total variance explained and were therefore omitted from the final model.

Two additional measures were included in the model runs presented in Table A.1 to capture additional aspects of political preferences including the proportion of Catholics in a Land and a dummy variable indicating whether or not a Land belonged to the East or the West as proxies for the existing political cultures (Almond and Verba 1965; Inglehart 1990; Inglehart and Abramson 1995; Goren 2004; Norris 2004; Goerres and Tepe 2011). The proportion of Catholics was used as a proxy for social conservativism, with data obtained from the Secretariat of German Bishops. An additional run included a variable denoting whether or not the government was controlled by a party from the Left, however, it was found not to be statistically associated with the outcomes examined in the paper and did not contribute to the variance explained and was omitted from the final model run.

The inclusion of additional variables listed in Table A.1 helped to increase the variance explained for each of the policy outcomes. Further, while the additional variables increased the explanatory strength of the model specifications, it did not change the majority of the results previously found in the more parsimonious model specification presented in the paper in Table 3. In both the parsimonious and fuller model specifications, the statistical significance of each variable did not change.

There are two situations however, where the regression coefficients differ. In the parsimonious model for naturalisation rates higher levels of real GDP/capita were associated with higher levels of naturalisation rates, while in the fuller specification presented in Table A.1 real GDP/capita carries a negatively signed coefficient. The change in sign is likely a product of the high degree of collinearity between real GDP/capita and the unemployment rate present in the fuller model. The second change is the sign for the proportion of leftist parties in office for Beamte PayLevel. In the parsimonious model the proportion of leftist parties in office carries a negative sign while in the fuller model specification in Table A.1 it carries a positive sign which supports prior expectations for the priorities of leftists parties presented in the paper. The difference in results is likely a product again of a collinearity issue between the strength of left parties in office and the other independent variables in the model. 


\section{References:}

Almond, G. and S. Verba. (1965) The Civic Culture: Political Attitudes and Democracy in Five Nations, an Analytic Study. (Boston: Little Brown).

Bräuninger, T. (2005) 'A Partisan Model of Government Expenditure', Public Choice. 125(3/4):pp.409-29.

Chang, E. (2008) 'Electoral Incentives and Budgetary Spending: Rethinking the Role of Political Institutions’, Journal of Politics 70(4):pp. 1086-97.

Crepaz, M.L. (1998). 'Inclusion versus Exclusion: Political Institutions and Welfare Expenditures', Comparative Politics. 31(1):pp.61-80.

Goerres A. and M. Tepe. (2011). 'Doing It for the Kids? The Determinants of Attitudes towards Public Childcare in Unified Germany', Journal of Social Policy, 41(2): pp349-72.

Goren, P. (2004) 'Political Sophistication and Policy Reasoning: A Reconsideration', American Journal of Political Science. 48(3):pp 462-78.

Huber, E. and J.D. Stephens. (2000) 'Partisan Governance, Women’s Employment, and the Social Democratic Service State’, American Sociological Review. 65(3):pp 323-42.

Huber, E. and J.D. Stephens. (2001) Development and Crisis of the Welfare State: Parties and Policies in Global Markets. (University of Chicago Press).

Inglehart, R. (1990) Culture Shift in Advanced Industrial Society (New Jersey: Princeton University Press).

Inglehart, R. and P. Abramson. (1994) Value Change in Global Perspective. (USA: University of Michigan Press).

Iversen, T. and D. Soskice. (2006) 'Electoral Institutions and the Politics of Coalitions: Why Some Democracies Redistribute More than Others', American Political Science Review. 100(2):pp.165-81.

Norris, P. (2004) Electoral Engineering: Voting Rules and Political Behavior. (Cambridge Studies in Comparative Politics).

Shelton, C.A. (2007) 'The Size and Composition of Government Expenditure', Journal of Public Economics. 91:pp2230-60. 


\section{APPENDIX B: INSTITUTIONAL CONSTRAINTS}

The following provides a more detailed look into the creation of the institutional constraint index used in the paper. Institutional constraints are institutional designs or outcomes that increase the difficultly for governments to agree on and pass legislation; alternatively referred to as veto players (Tsebelis 1995), veto points (Immergut 1990), or consensual institutions (Lijphart 1999). Institutional constraints can be thought of as items that increase the number of preferences or actors present in the decision making process. By increasing the number of actors with a voice on policy it makes it more difficult for any particular set of actors to shift policy in a direction that favours their specific interests to the determent of others following the veto players or more accurately the veto points argument.

The scale created here ranges from zero to five where the presence of a trait that increase the number of actors with a voice in the decision making process is scored as a one. The scale adds together the number of traits each Land has to represent the number of constraints present in a given year following the approach used by Huber and Stephens (1993, 2001, 2003) and Brooks and Manza (2007).

The traits that were used in the index include:

PPR versus PR: pure proportional representation (PR) systems are scored as a one. PPR systems produce a slightly more majoritarian outcome that has to be adjusted through various additional mechanisms (Massicotte 2003).

Effective Number of Parties: Although multiple parties may be present in the legislature, if one party holds the majority of seats, smaller parties are in less of a position to set the agenda. When the effective number of parties is greater than 2 this variable receives a one.

Minimum Winning Coalition: When the ruling coalition holds a majority of seats it should be able to pass legislation as each Land uses simple majority voting rules. Therefore, when the minimum winning coalition holds less than $51 \%$ of the seats in the legislature it must work with those outside the coalition. Cabinets that hold less than $51 \%$ of the seats in the legislature are scored as a one.

Remainder Rule: There is a degree of variation in the rules used to allocate remaining seats in the legislature. The literature notes that the Sainte-Laguë rule produce a more proportional outcome (and increases the number of actors with different preferences) than the d'Hondt (or Hare-Nremeyer) approach (Massicotte 2003). Länder that use the Sainte-Laguë rule are scored as a one.

Open versus Closed Party Lists: Open party lists allow the candidates a greater degree of autonomy from the party line than closed lists (where the part determines the order of appointment). Therefore, open list rules receive a score of one. 
Figure B.1: Distribution of Traits
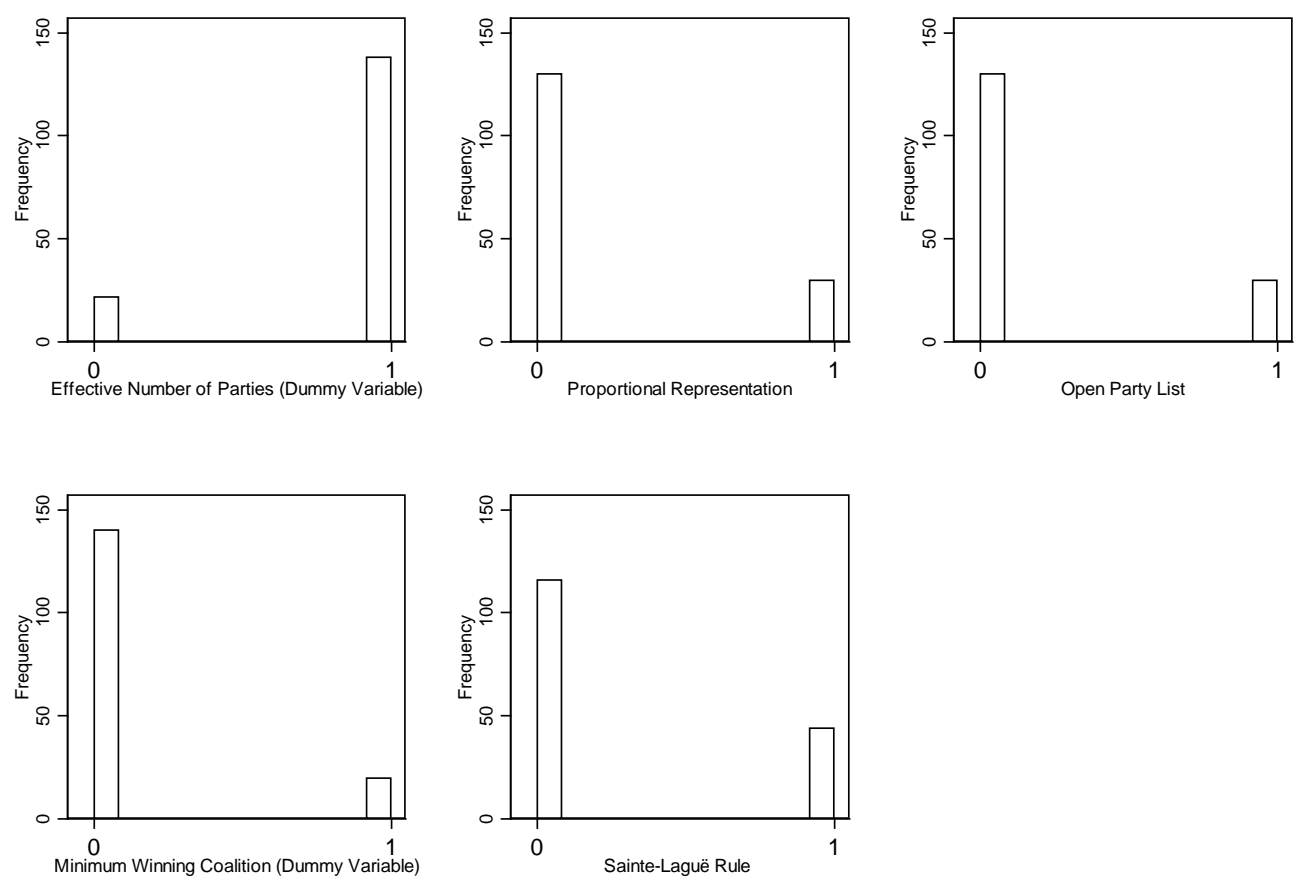

Each of the components used to construct the index demonstrates variation across the Länder. Figure B.1 demonstrates the variation providing the number of times each trait is observed. The institutional constraint variable was calculated for each Land-year allowing for changes in the effective number of parties and minimum winning coalition variables. The scale has a Cronbach's alpha of 0.5814 which produces a higher level of internal reliability regarding the scaled items used compared the alternative measure produced by Freitag and Vatter (2009). Using the data provided in the work by Freitag and Vatter (2009) we recreated their measure of institutional variation by running a factor analysis using principle component factor method with a varimax rotation. However, an examination of their data revealed an internal reliability of the set of variables used (i.e., Chronbach's alpha) of only 0.128 and a KaiserMeyer-Olkin estimate which indicates the level of commonality between the variables of 0.3623 which below traditionally acceptable levels of 0.50 . 
Figure B.2: Distribution of Institutional Constraints across the Länder (200110)

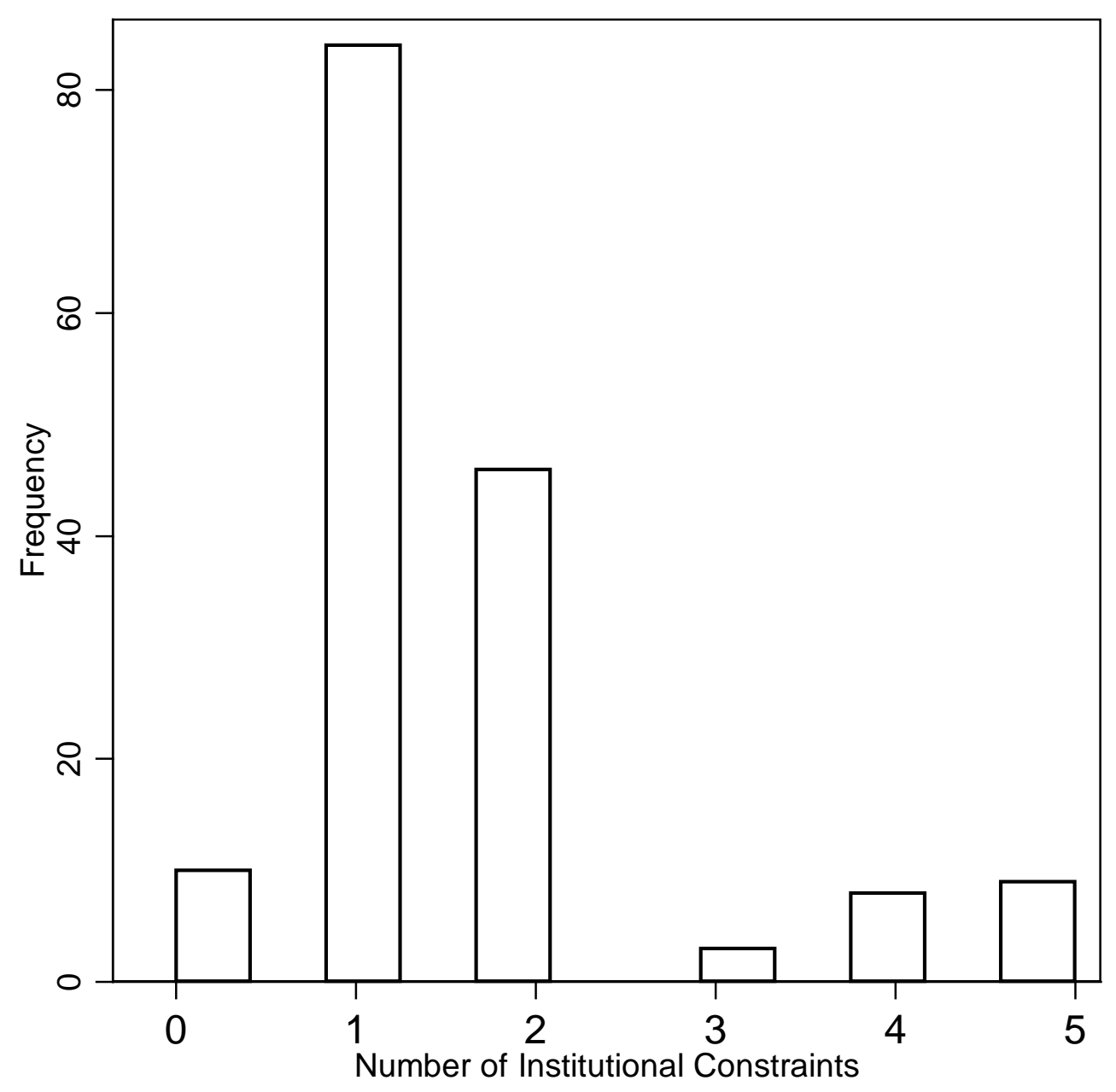

Figure B.2 shows the distribution in the number of institutional constraints over the time period examined in the paper. We see that over the time period there is a range in the number of institutional constraints present across the Länder with the modal number of constraints at 1 and ranging from 0 (in Brandenburg from 2001-10) to 5 (in Hamburg 2002-10). 


\section{Figure B.3: Average Number of Institutional Constraints by Land}

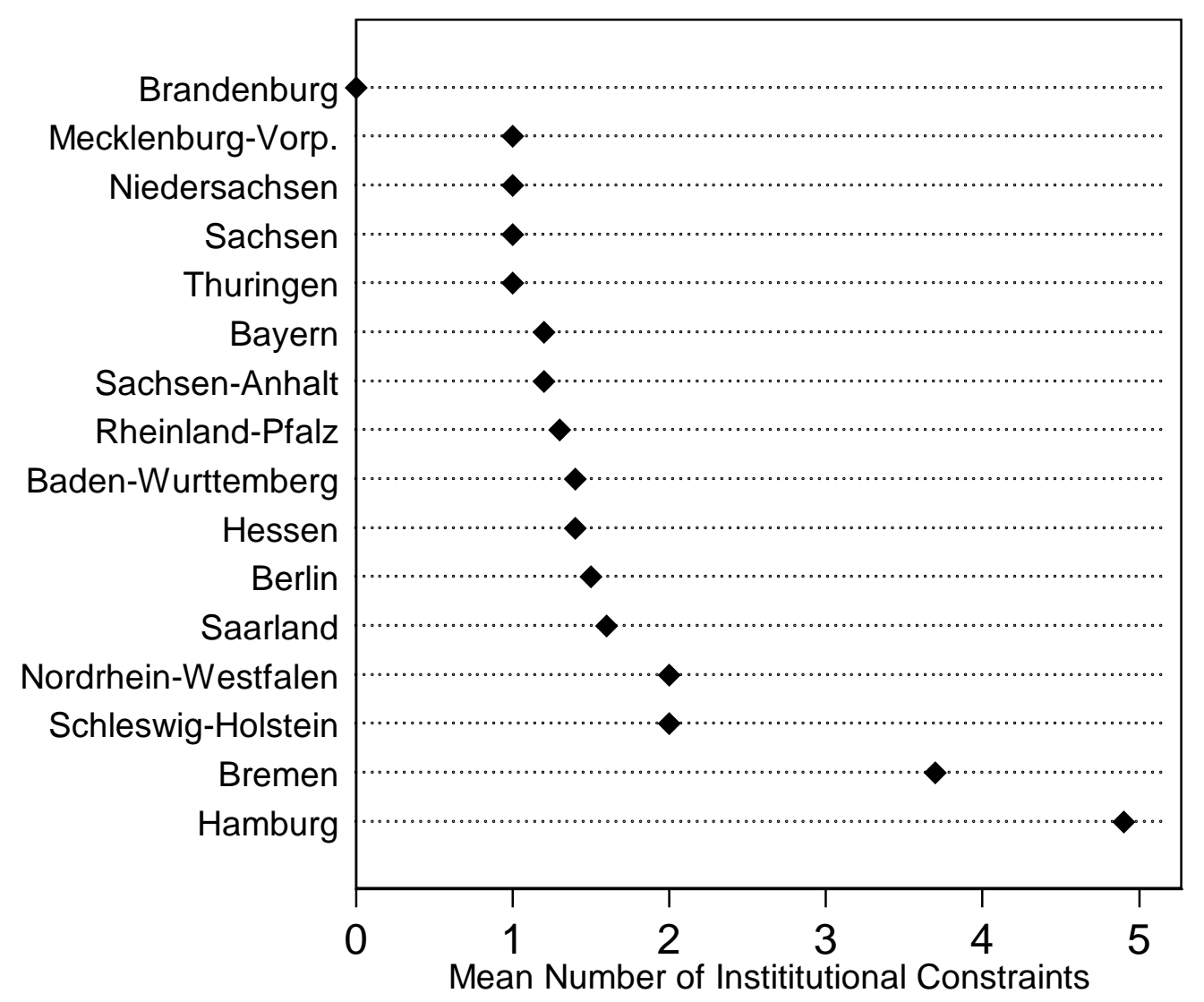

Finally, Figure B.3 shows the mean number of institutional constraints present in each Länder from 2001-10. Figure B.3 demonstrates that the full potential range of values from zero to five is observed with many states varying between one and two constraints over the time period, which is indicated by the mean location between the values of one and two. Additionally, Bremen varies between three and four constraints and Hamburg between four and five.

\section{References:}

Brooks, C. and Manza, J. (2007) Why Welfare States Persist: The Importance of Public Opinion in Democracies, The University of Chicago Press Books.

Huber, E. and Stephens, J.D. (1993) 'Political Parties and Public Pensions', Acta Sociologica 36(4):309-25.

Huber, E and Stephens J.D. (2000) 'Partisan Governance, Women's Employment, and the Social Democratic Service State’, American Sociological Review. 65(3): 323-42.

Huber, E. and Stephens, J.D. (2001). Development and Crisis of the Welfare State: 
Parties and Policies in Global Markets, University of Chicago Press.

Immergut, E.M. (1990) 'Institutions, Veto Points, and Policy Results: A Comparative Analysis of Health Care’, Journal of Public Policy. 10(4):391-416.

Lijphart, A. (1999) Patterns of Democracy. Government Forms and Performance in ThirtySix Countries, New Haven: Yale University Press.

Massicotte, L. (2003) 'To Create or to Copy? Electoral Systems in the German Länder', German Politics. 12(1): pp.1-22.

Tsebelis, G. (1995) 'Decision Making in Political Systems: Veto Players in Presidentialism, Parliamentarism, Multicameralism, and Multipartyism’, British Journal of Political Science 25:289-326. 
APPENDIX C: Variation in Independent Variables by Länder

Figure C.1: Variation in Real GDP/Capita by Länder over Time

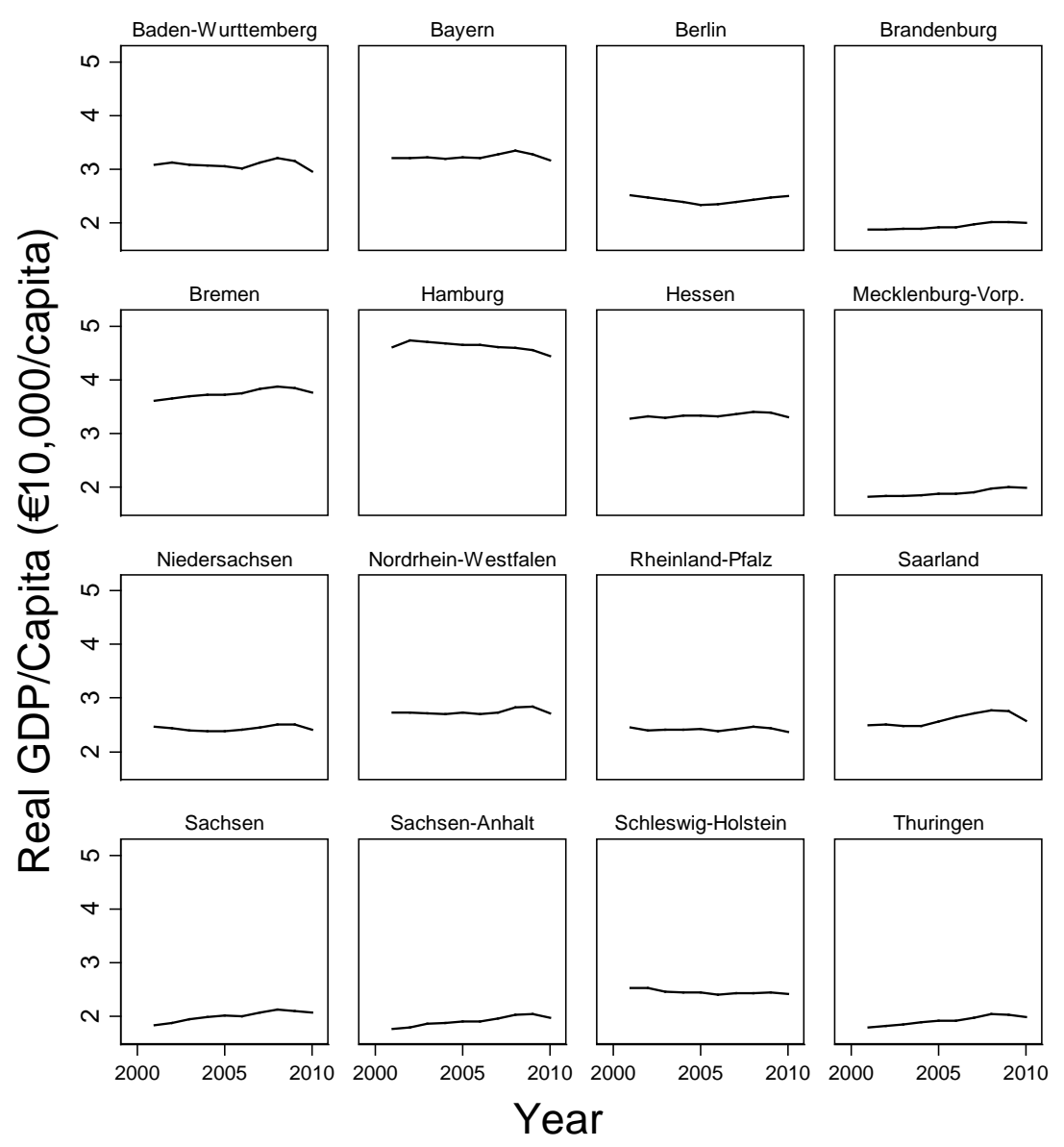


Figure C.2: Variation in the Strength of Left by Länder over Time
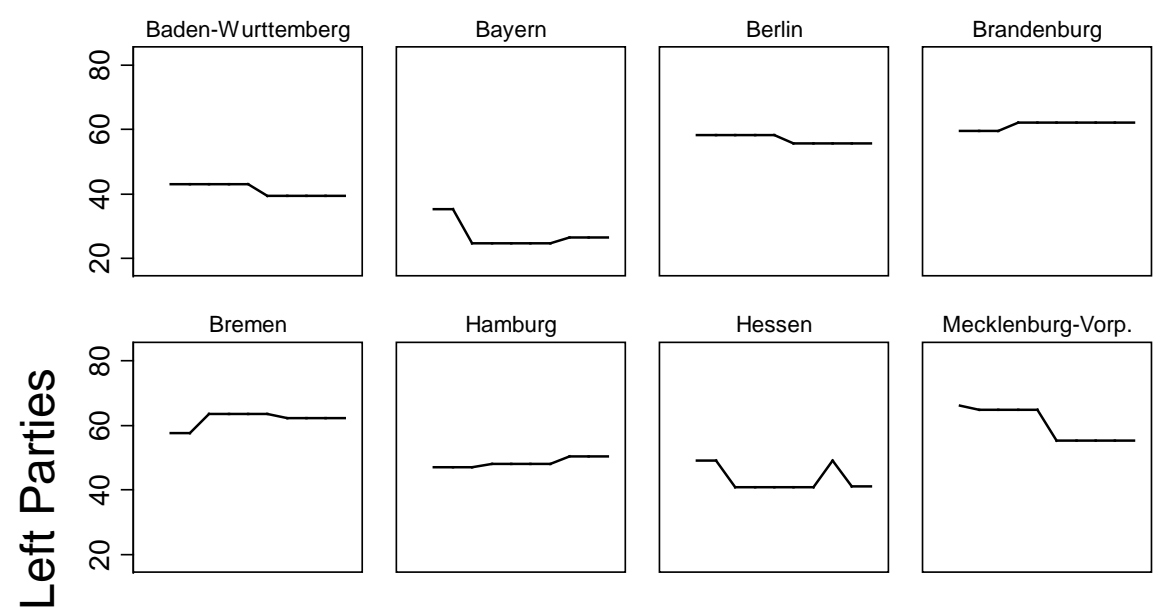

Mecklenburg-Vorp.

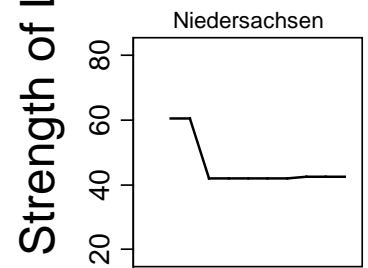

Nordrhein-Westfalen

Rheinland-Pfalz
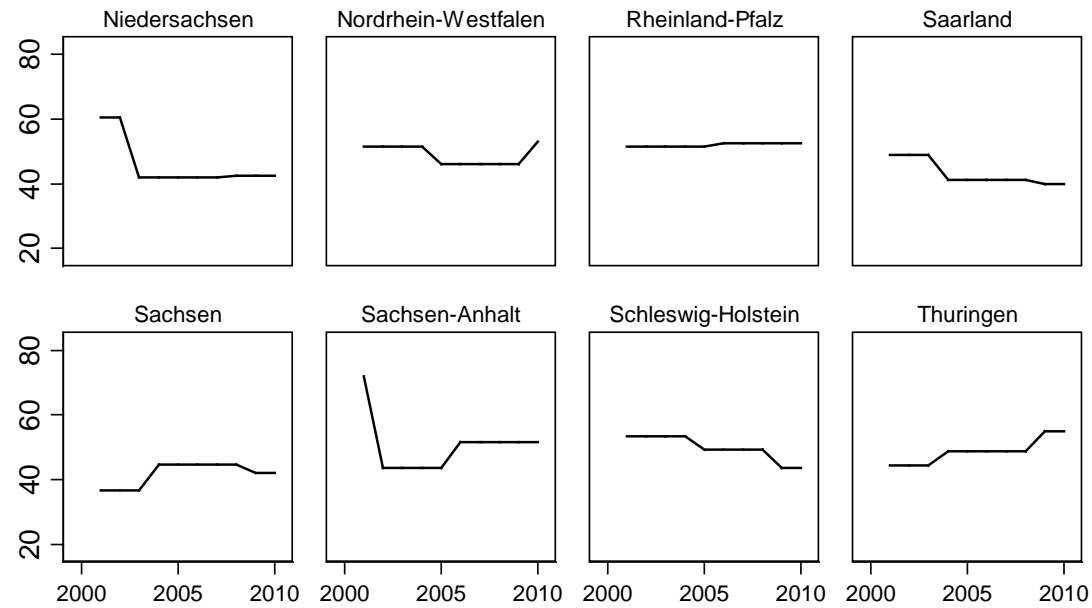

Sachsen-Anhalt

Schleswig-Holstein

Thuringen
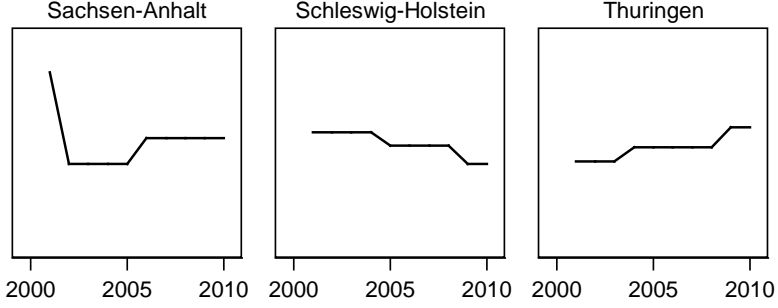

Year 
Figure C.3: Variation in Institutional Constraints by Länder over Time

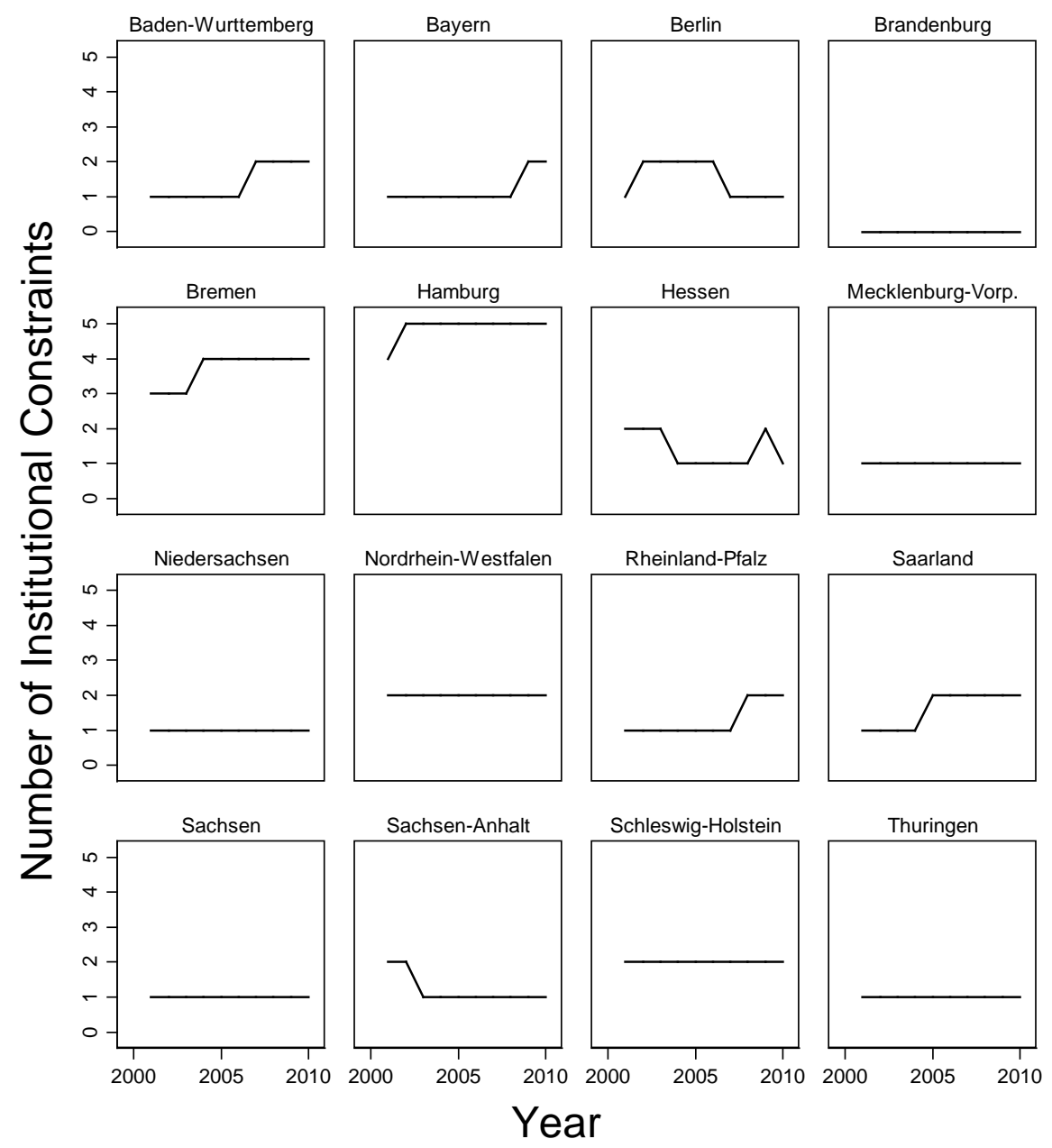




\section{APPENDIX D: MARGINAL EFFECTS PLOTS}

\section{Figure D.1: Marginal Effects Plots for Prison Occupancy Rates}
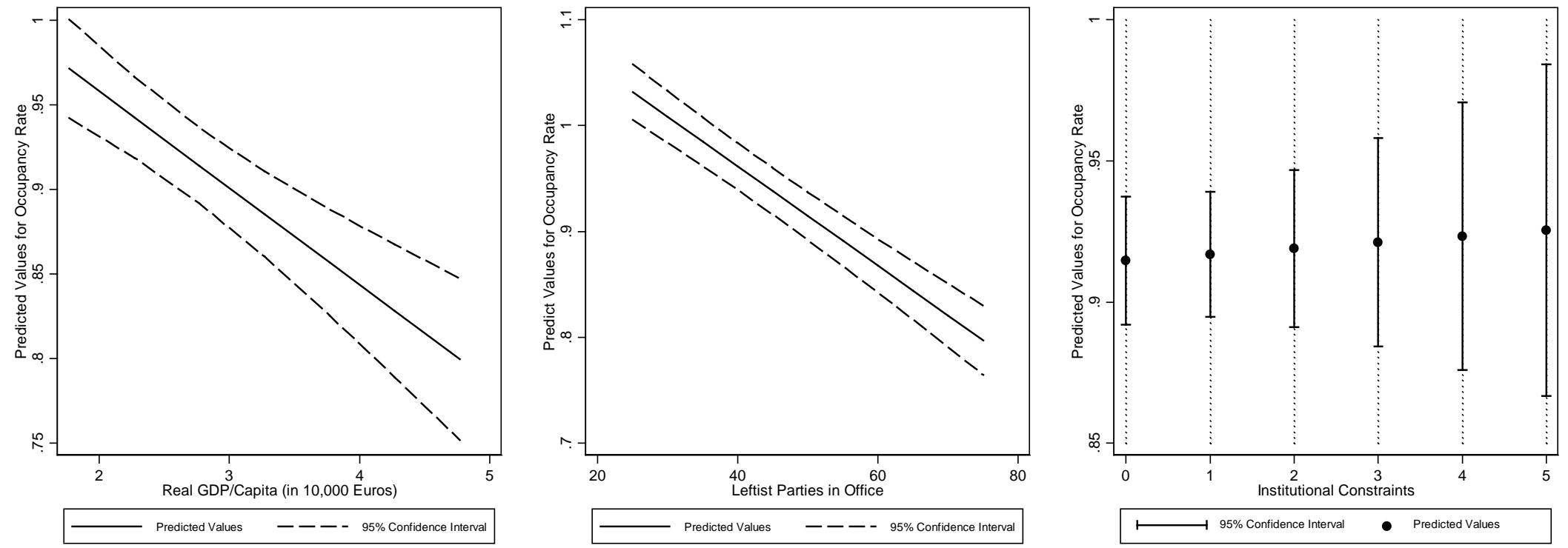

Figure D.1 provides a graphical display for the marginal effects for each of the three independent variables included in the model runs presented in Table 3 for prison occupancy rates. Over the observed values for real GDP/capita (in 10,000 Euros), holding the proportion of leftist parties at its mean value and institutional constraints at it median value, as real GDP/capita increases, the predicted value for occupancy rates decreases. A similar pattern is observed over the observed range of leftist parties in office, where real GDP/capita is held at its mean value and institutional constraint variable is held at its median value. In this model specification for occupancy rates institutional constraints was found to not be statistically associated with occupancy rates, holding real GDP/capita and the proportion of leftist parties in office at mean values, the confidence interval shows a potential positive or negative association over the range of possible values. Unlike real GDP/Capita and the 
proportion of leftist parties in office, the institutional constraint variable is not continuous and is therefore not plotted with a line. Instead, the predicted values for each of the outcomes at the different discrete values of the constraint variable are plotted with points and confidence intervals around those values in Figures D.1-D.4. 
Figure D.2: Marginal Effects Plots for Naturalisation Rates
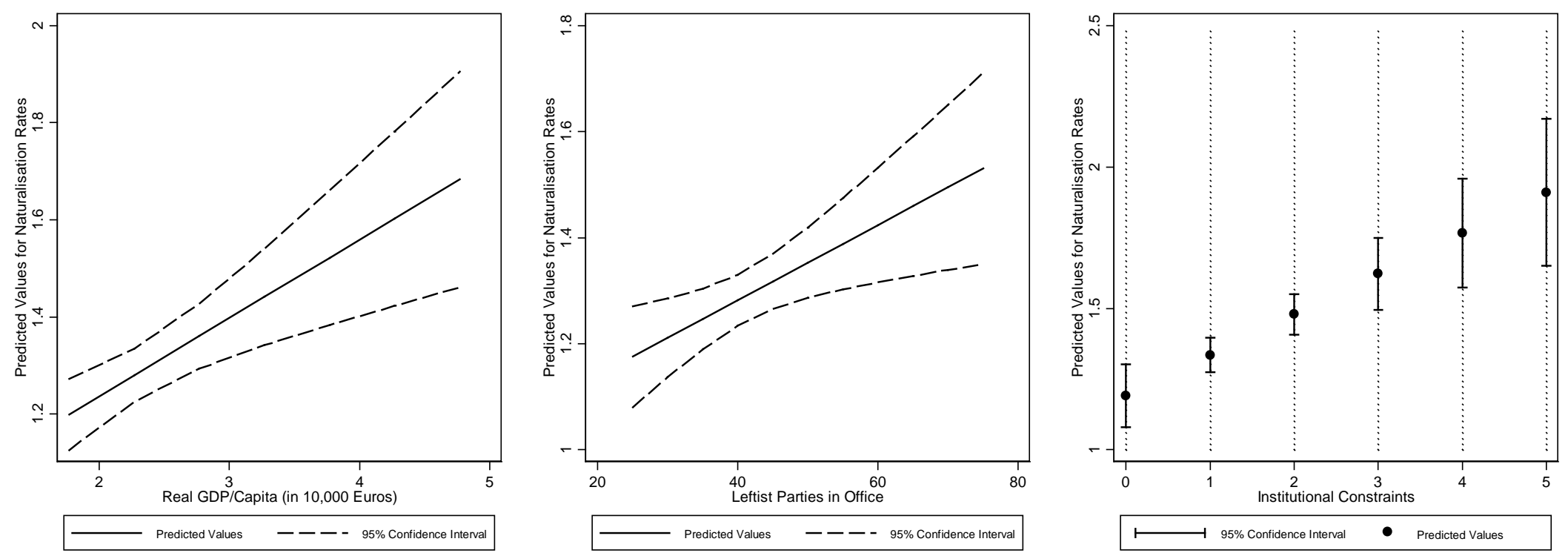

Figure D.2 provides a graphical display for the marginal effects for each of the three independent variables included in the model runs presented in Table 3 for naturalisation rates. Over the observed values for real GDP/capita (in 10,000 Euros), holding the proportion of leftist parties at its mean value and institutional constraints at it median value, as real GDP/capita increases, the predicted value for naturalisation rates increase. A similar pattern is observed over the observed range of leftist parties in office, where real GDP/capita is held at its mean value and institutional constraint variable is held at its median value. Holding real GDP/capita and the proportion of leftist parties in office at mean values, more institutional constraints are observed to carry a positive association with naturalisation rates. 
Figure D.3: Marginal Effects Plots for Beamte Pay Level
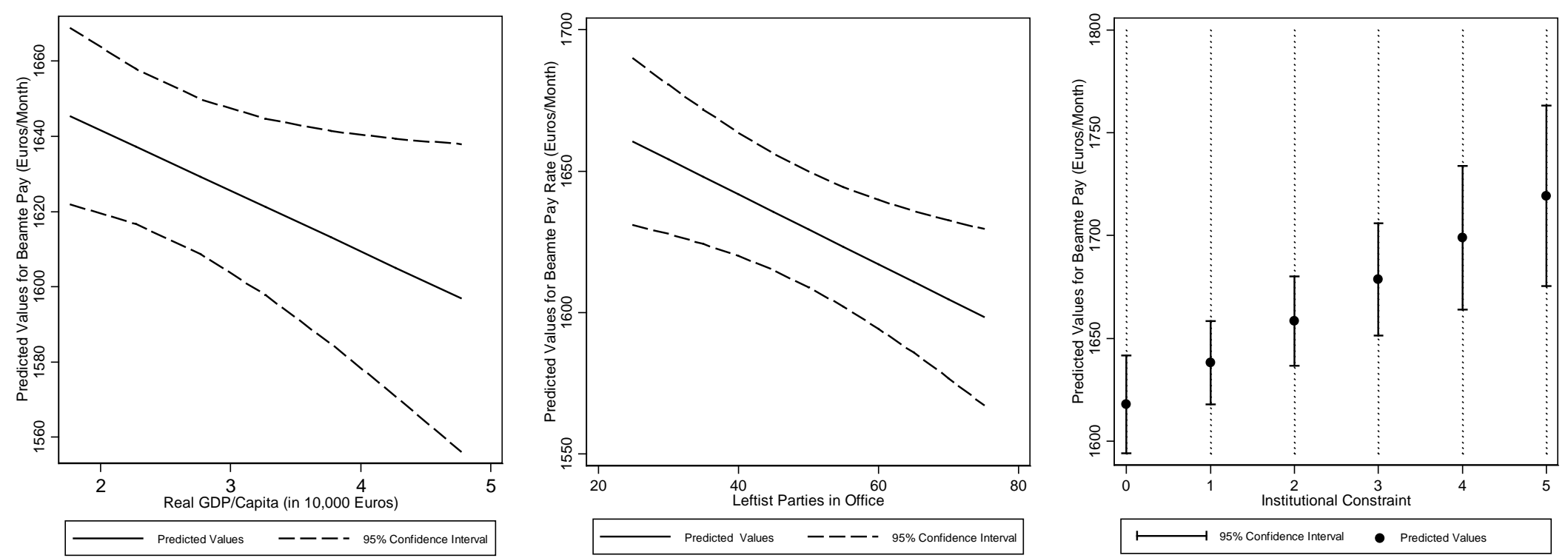

Figure D.3 provides a graphical display for the marginal effects for each of the three independent variables included in the model runs presented in Table 3 for Beamte pay. Over the observed values for real GDP/capita (in 10,000 Euros), holding the proportion of leftist parties at its mean value and institutional constraints at its median value, higher levels of real GDP/capita are associated with lower predicted value for Beamte pay. A similar pattern is observed over the observed range of leftist parties in office, where real GDP/capita is held at its mean value and institutional constraint variable is held at its median value. Holding real GDP/capita and the proportion of leftist parties in office at mean values, more institutional constraints is observed to carry a positive association with Beamte pay. 
Figure D.4: Marginal Effects Plots for University Enrolment
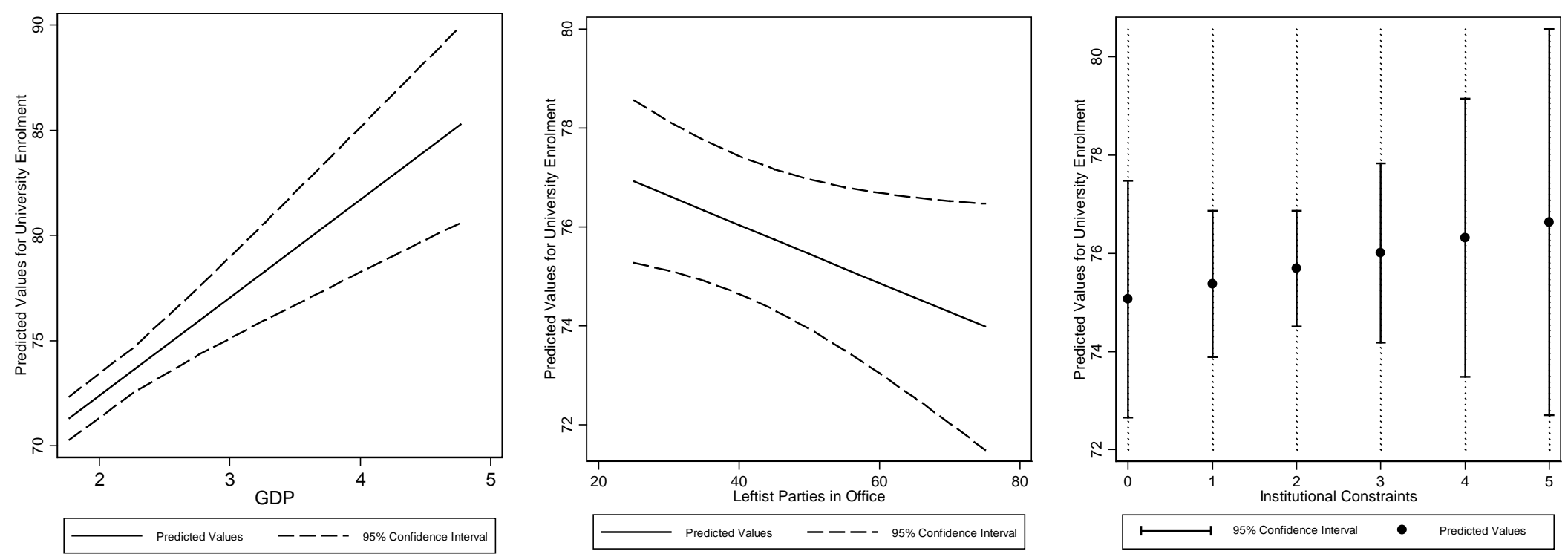

Figure D.4 provides a graphical display for the marginal effects for each of the three independent variables included in the model runs presented in Table 3 for the proportion of eligible students enrolling in university. Over the observed values for real GDP/capita (in 10,000 Euros), holding the proportion of leftist parties at its mean value and institutional constraints at its median value, higher levels of GDP/capita are associated with higher predicted values for university enrolment. The opposite pattern is found over the observed range of leftist parties in office; where real GDP/capita is held at its mean value and institutional constraint variable is held at its median value, an increase in the proportion of seats held by leftist parties is associated with a decrease in predict university enrolment. In this model specification for university enrolment, institutional constraints was found to not be statistically associated with changes in enrolment, holding real GDP/capita and the proportion of leftist parties in office at mean values, the confidence interval shows a potential positive or negative association over the range of possible values. 